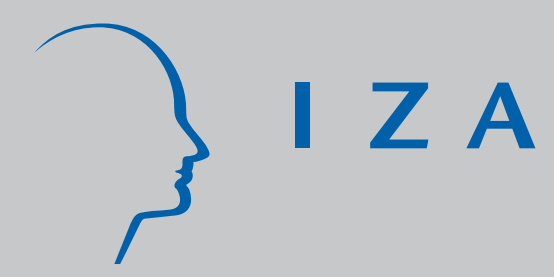

IZA DP No. 3740

Ethnic Intermarriage among Immigrants:

Human Capital and Assortative Mating

Barry R. Chiswick

Christina A. Houseworth

September 2008 


\title{
Ethnic Intermarriage among Immigrants: Human Capital and Assortative Mating
}

\author{
Barry R. Chiswick \\ University of Illinois at Chicago \\ and IZA \\ Christina A. Houseworth \\ University of Illinois at Chicago \\ and Litigation Analytics
}

Discussion Paper No. 3740

September 2008

\author{
IZA \\ P.O. Box 7240 \\ 53072 Bonn \\ Germany \\ Phone: +49-228-3894-0 \\ Fax: +49-228-3894-180 \\ E-mail: iza@iza.org
}

Any opinions expressed here are those of the author(s) and not those of IZA. Research published in this series may include views on policy, but the institute itself takes no institutional policy positions.

The Institute for the Study of Labor (IZA) in Bonn is a local and virtual international research center and a place of communication between science, politics and business. IZA is an independent nonprofit organization supported by Deutsche Post World Net. The center is associated with the University of Bonn and offers a stimulating research environment through its international network, workshops and conferences, data service, project support, research visits and doctoral program. IZA engages in (i) original and internationally competitive research in all fields of labor economics, (ii) development of policy concepts, and (iii) dissemination of research results and concepts to the interested public.

IZA Discussion Papers often represent preliminary work and are circulated to encourage discussion. Citation of such a paper should account for its provisional character. A revised version may be available directly from the author. 


\section{ABSTRACT}

\section{Ethnic Intermarriage among Immigrants: Human Capital and Assortative Mating*}

This paper analyzes the determinants of interethnic marriages among immigrants in the United States. The dependent variable is intermarriage across ethnic groups and the inclusion of the explanatory variables is justified by a simple rational choice economic model. A binomial logistic regression is estimated using data from the 1980 US Census, the last Census where post-migration marriages can be identified. Results show that the probability of intermarriage increases the longer a migrant resides in the U.S. and the younger the age at arrival. Both relationships can be attributable to the accumulation of US-specific human capital and an erosion of ethnic-specific human capital. Inter-ethnic marriages are more likely between individuals with similar education levels, providing evidence of positive assortative mating by education for immigrants. Construction of the availability ratio for potential spouses and group size are unique to this study, providing a more accurate measure of the marriage market by using data from several Censuses. Intermarriage is lower the greater the availability ratio and the larger the size of the group. Linguistic distance indirectly measures the effect of English language ability at arrival and is found to be a significant negative predictor of intermarriage. Those who report multiple ancestries and who were previously married are more likely to intermarry.

JEL Classification: J12, J15, J61, F22

Keywords: immigrants, marriage, ethnicity/ancestry

Corresponding author:

Barry R. Chiswick

Department of Economics

University of Illinois at Chicago

601 South Morgan Street

Chicago, IL 60607-7121

USA

E-mail: brchis@uic.edu

\footnotetext{
* We would like to thank all of those who made helpful comments at the Society of Labor Economists Meetings 2008 and the IZA Third Migrant Ethnicity Meeting in 2007.
} 


\section{Introduction}

Since the Immigration and Nationality Act Amendments of October 3, 1965, there has been a steady increase in the flow of immigrants to the United States. According to the Department of Homeland Security, there were 300,000 legal permanent residents admitted to the US in 1970, about 700,000 admitted in 1990, and 1.12 million in $2005 .^{1}$ Pat Buchanan and others have argued that immigration flows will alter the character and culture of the country in undesirable ways (Buchanan 2006). The validity of this concern depends on the dimensions of assimilation of interest and how fast immigrant groups assimilate to the US culture and economy. For the purposes of this paper, the term assimilation will refer to a specific type of structural assimilation, as defined by Gordon (1964). Structural assimilation refers to the process by which the foreign born are accepted into institutions of the host country. One signal of structural assimilation is an individual's economic status, such as education, earnings, or occupation. Another signal of assimilation is the extent of intermarriage by the foreign born, where marriages among individuals of different ethnic groups are commonly referred to as ethnic intermarriages.

Assimilation is the process by which the foreign born acquire human capital specific to the host country. ${ }^{2}$ This perspective dates back to Chiswick (1978) who demonstrated that economic assimilation is a process occurring after immigration, with immigrants reaching parity in earnings with the native born at about 12 to 15 years after entering the country, controlling for age and education, among other variables. Countryspecific human capital consists of investments in language and culture, as well as knowledge about local job markets and specific occupations. For a variety of reasons, intermarriage by an immigrant group in the US may be considered one signal of the level of assimilation, that is, the level of US-specific human capital accumulation.

It facilitates marriage if there is sophisticated and complicated verbal communication between spouses. Migrants from different linguistic groups that marry

\footnotetext{
${ }^{1}$ While reportedly 1.7 million legal permanent resident visas were issued in 1990, this includes about 1.0 million illegal aliens who received permanent resident alien status under one of the two provisions of the 1986 Immigration Reform and Control Act. Therefore, about 700,000 of the 1990 immigrants are comparable to the 300,000 immigrants admitted in 1970.

${ }^{2}$ The acquisition of US-specific human capital need not necessarily imply an eroding of the individual's ethnic-specific human capital.
} 
will need to learn a common language to communicate effectively, and the host country language is likely the most cost effective language to learn. Considering that most immigrants from non-English speaking countries make large investments in English language skills upon arrival in the US, learning a third language (i.e., that of the spouse) is not an efficient allocation of time and other resources. Migrants from the same linguistic ethnic group are likely to speak their native language at home, and this reduces the need to learn and speak the language of the host country. There is more incentive for intermarried individuals to acquire English language skills and, therefore, intermarried immigrants are likely to have higher levels of English language ability than their endogamously married counterparts. ${ }^{3}$ Greater English language ability corresponds to a higher level of assimilation.

Moreover, there is literature showing empirically that intermarriage is an indicator of assimilation. Intermarried immigrants in Australia, France, and the US earn significantly higher incomes than their endogamously married counterparts, even after controlling for human capital endowments unrelated to marriage (Meng and Gregory, 2005; Meng and Meurs, 2006; Kantarevic, 2004). However, there is also evidence that the direction of causality runs in the opposite direction, and that higher earnings are a consequence of intermarriage rather than an indicator or predictor of intermarriage (Meng and Gregory, 2005; Meng and Meurs, 2006). Holding all else fixed, favorable labor market outcomes are often an indication of assimilation as high earnings in the US are associated with a good knowledge of local labor markets and substantial English proficiency. Because intermarried immigrants earn higher incomes than their endogamously married counterparts, intermarried couples appear to be more assimilated. Furthermore, intermarriage is an index of social assimilation and acceptance of the immigrant group by other ethnic groups. Those groups whose members are bound to the ethnic community, or whose members are shunned by other groups, are less likely to intermarry.

This paper examines the determinants of ethnic intermarriage (or exogamous marriage) among immigrants to the US, where interethnic marriage is defined as the

\footnotetext{
${ }^{3}$ Endogamy refers to a marriage between two individuals of similar ethnic backgrounds.
} 
marital union between two individuals of different ethnic backgrounds/ancestries. ${ }^{4}$ Immigrant ethnicity is measured using responses to the two questions on ancestry and country of birth in the US Census of Population (Appendix Tables A-1 and A-2). Typically, intermarriage rates are low among immigrants in the US (Appendix Tables A3 and A-4) but rates differ by ethnicity. The purpose of this paper is to address the importance of individual and environmental characteristics that are responsible for influencing the probability of intermarriage. A study of the determinants of intermarriage is imperative for understanding the underlying factors that may influence immigrant adjustment and the adjustments of their children.

Among other results, support is found for positive assortative mating by education level for men and women. Several variables are used to construct ethnic marriage market conditions, where an availability ratio and ethnic group size are found to have significant effects on the probability of intermarriage. This paper explores the relationship between ethnic-specific human capital and US-specific human capital. Findings indicate that the probability of intermarriage increases with educational attainment and as the age of migration falls, as well as with duration in the U.S. Current English language skill and intermarriage are highly endogenous, however, the relationship between the "linguistic distance" of the immigrant's mother tongue from English and intermarriage is found to be negative.

The paper is organized as follows. Section II provides a review of the literature on the determinants of ethnic intermarriage for immigrants. In Section III, a simple economic model of intermarriage is presented. A description of the data set is in Section IV, followed by the empirical results in Section V, and a conclusion in Section VI.

\footnotetext{
${ }^{4}$ In this study intermarriage for a person of mixed background is defined as a marriage to a person of an ethnicity other than either of the respondent's ethnicities. Furthermore, a marriage between a native born and an immigrant of a similar ethnic background is not considered an inter-ethnic marriage. There is no way to distinguish between second or higher order generations in the 1980 Census or later Censuses. Consider a German immigrant married to a native born of German decent. This marriage will be considered endogamous if the native born marks German as their first choice for the ancestry question on the Census. This may bias the intermarriage rate downward, if the native born is from much earlier generations of immigrants, and therefore more American than German per se. However, the alternative to this would be to consider the above couple intermarried, which would then bias the intermarriage rate upward if the native born are from relatively recent immigrant arrivals.
} 


\section{Literature Review: Determinants of Ethnic Intermarriage}

There is a large literature on the economics of marriage in which, among other things, the potential gains from marriage are discussed. The underlying assumption of the model employed in this paper is that benefits accrue to those who marry within their ethnicity. As discussed in Becker’s “A Theory of Marriage”, assortative mating implies that there are benefits from marriage that are most efficiently utilized when individuals match up with people of similar traits (Becker, 1974). Such characteristics may be education, intelligence, health, and religion. There are numerous benefits to marrying within one’s group, derived from the activities performed jointly in marriage, such as rearing children, joint decision making regarding the distribution of time and money, and many others.

The determinants of intermarriage can be categorized in one of three groups: preferences, opportunity for contact, and factors that influence both. "Preferences" describe the degree of importance that an individual attaches to marrying someone within their ethnic group. “Opportunity for contact” refers to availability and accessibility to potential spouses in the individual's ethnic group. Education and military status are discussed separately, as they may affect both an individual's marriage market and their individual preferences.

Preferences for a partner of a similar ethnic background can be altered by a variety of factors, such as language, levels of human capital, modernization, and a host of other characteristics ${ }^{5}$. Researchers have used language and education as proxies for levels of ethnic human capital. Continuing facility with one's native language has been found to be negatively related to intermarriage in Anderson and Saenz (1994). Kalmijn (1991) uses the term modernization, which correlates to high levels of US-specific human capital, and hypothesizes that the US-born children of immigrants are more likely to intermarry than their immigrant parents. Alba and Golden (1986) look at rates of ethnic intermarriage among the native born in the US. They find a positive relationship between immigrant cohort and intermarriage, that is, intermarriage rates increase with generation

\footnotetext{
${ }^{5}$ Ethnic-specific human capital refers to capital that is productive in terms of ethnicity (eg., knowing how to celebrate ethnic holidays). US-specific human capital refers to human capital that is productive in the host country, but is general across ethnic groups in the US (eg., English language).
} 
in the US. Alba and Golden (1986) also find that individuals with mixed ancestry are more likely than the children of endogemously married parents to intermarry. In addition, Gilbertson, et al. (1996) find that second-generation Hispanics with mixed ancestry living in New York are more likely to intermarry than second-generation Hispanics of a single Hispanic ancestry.

Opportunity for contact is indicated by the size of the ethnic group, the size of the population as a whole, and the number of the opposite sex in relation to the number of individuals of the same sex. The ratio of available men to women in a given region has commonly been used to explain various behaviors in Schoen (1983), Lichter, LeClere \& McLaughlin (1991), Fossett \& Kiecolt (1991), Fitzgerald (1991), Brien (1997), and Goldman et al (1984). Lichter et al. (1992) find a negative relationship between availability ratios and age at first marriage. They find that individuals marrying at later ages typically face a lower availability ratio than those marrying early in life. Including only employed males produces an availability ratio that focuses on "marriageable” men (Wilson, 1987; Lichter et al., 1992; Wood, 1995; Fitzgerald, 1991; Brien, 1997; Fossett and Kiecolt, 1991; Lichter et al., 1991; South \& Loyd, 1992a).

The probability of finding a "good match" will increase not only as the ratio of opposite to same gender grows, but also the larger the absolute size of the population. Alba and Golden (1986) look at ethnic intermarriage among European origin groups in the US. They find a significant and negative relationship between group size and intermarriage. Other studies come to the same conclusion (Gilbertson, et al, 1996).

Education may affect the probability of intermarriage through three venues. Education may alter an individual's preferences for marrying outside their ethnicity. As discussed in Cohen (1977), those who have higher levels of education may have spent more time among people of diverse backgrounds which may decrease aversion to (or increase understanding of) other groups. The effect that education may have on preferences for marrying outside one's ethnicity is referred to by Furtado (2006) as the “cultural adaptability effect”.

Education is also examined as a determinant of intermarriage in other papers with most of the findings supporting the hypothesis that the highly educated are more likely to intermarry (Lieberson and Waters, 1988; Schoen and Wooldredge, 1989; Sandefur and McKinnell, 1986; Meng and Gregory, 2005; Lichter and Qian, 2001). However, Furtado 
(2006) finds no support for the cultural adaptability effect of education after controlling for the other avenues through which education may affect the probability of intermarriage.

Highly educated individuals may also be less attached to their family or community of origin as they left the family and ethnic environment to obtain higher education (Kalmijn, 1998). Furtado (2006) refers to this effect as the "enclave effect". She assumes that individuals remain in the area where they received the education that removed them from the enclave and concludes that the enclave effect is well measured by the proportion of the individual's ethnic group in the geographical area.

If there is assortative mating by education, education also affects the size of the relevant marriage market. Furtado (2006) examines the effect of education on the probability of intermarriage by controlling for the average level of education within the group for $2^{\text {nd }}$ generation immigrants using 1970 Census data. Furtado finds that the effect is strongest for immigrants from countries whose mean education values are very different from the rest of the population. Individuals with educational levels much higher or much lower than their ethnic group's average have a significantly higher probability of intermarriage. Similar results are found in Lehrer (1998) in connection with religious intermarriage.

The literature suggests that several individual and environmental characteristics are important in determining the probability of intermarriage. This research draws on some of the techniques used in the literature such as the availability ratio. However, a more accurate measure of the availability ratio is taken by using several Censuses to construct this variable. In addition to expanding on previous methods, this paper addresses some issues that were previously overlooked. For instance, using current English language skill as a determinant of intermarriage can add complications as it is likely to be endogenous to the probability of intermarriage. An alternative exogenous measure of language, linguistic distance, is used here.

\section{Theory and Hypotheses}

In general, economic theories of marriage assume that individuals make marriage decisions by comparing costs and benefits. Chiswick and Lehrer (1991) and Lehrer (1998) model intermarriage using a marginal cost/marginal benefit model. The process of dating and finding an acceptable spouse is similar to a job search model. The marginal 
cost of continuing to search is the delay in marriage and family formation, and the foregone benefits of marrying the current partner. The marginal benefit of continuing to search for a partner arises from the probability of finding a more suitable partner, in particular, a partner who is personally, financially and ethnically more compatible. See Furtado (2006) for a good dynamic search model.

Because the data are on marriages that have already taken place, an ex post analysis will be used, while the discussion and interpretation will continue to relate the variables of the model to a search process.

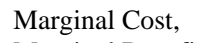

Marginal Benefit

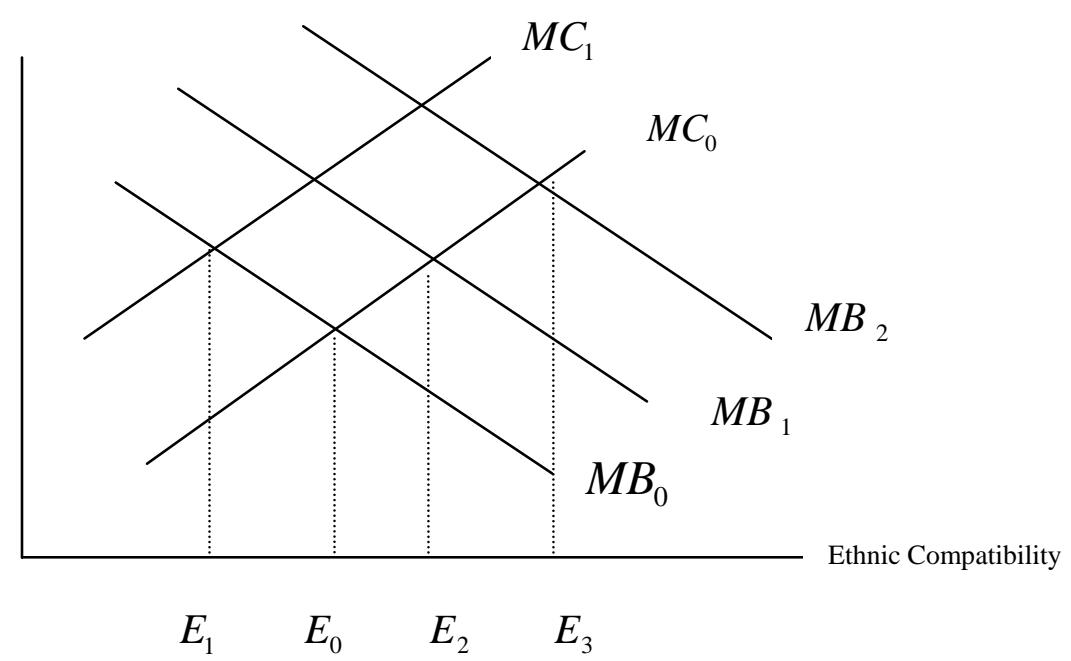

\section{FIGURE 1: MARGINAL COST AND MARGINAL BENEFIT OF ETHNIC}

COMPATIBILITY $M B_{0}$ : Immigrated as children $M B_{1}$ : Immigrated as young adults $M B_{2}$ : Immigrated as older adults

In Figure 1 the optimal level of ethnic compatibility in a spouse is measured on the horizontal axis, while marginal costs and marginal benefits of ethnic compatibility are measured on the vertical axis. ${ }^{6}$ High levels of ethnic compatibility are associated with a low probability of intermarriage. The marginal cost of search is upward sloping, reflecting the rising cost of search as individuals seek higher levels of ethnic compatibility. The marginal benefit of additional search for ethnic compatibility is

\footnotetext{
${ }^{6}$ It should be noted that the theory predicts changes in the probability of intermarriage, a continuous variable, while the data measures intermarriage as a dichotomous variable. However, there is no qualitative effect on the conclusions.
} 
downward sloping, indicating the smaller incremental benefits in terms of greater compatibility from additional units of search.

\section{A. Individual Characteristics}

The 1980 Census data, the last US Census to ask age at first marriage, show that the median age at first marriage was 22 years for females and 25 years for males. Preferences for intermarriage may change over time; a 30 year old may have different preferences than those they had when they were 22. In addition, an individual's ethnic marriage market becomes smaller as they age, as other potential mates in their ethnic group marry or otherwise leave the marriage market.

There are a couple of ways to think about this phenomenon. Suppose the process of searching for a spouse begins with the most ethnically compatible candidates given consideration first and the least ethnically compatible candidates considered last. Because time spent searching indicates a later age at first marriage, later marriages will involve less compatibility and are less likely to be endogamous. Basically, as individuals age, the number of ethnically compatible members of the opposite sex that are single decreases, increasing the cost of search. Thus, as age at first marriage increases for immigrants, the marginal cost of search for ethnic compatibility will increase and the probability of intermarriage increases. Recent findings by Lehrer (2008), for example, show that women who marry at an older age are more likely to make tradeoffs in regards to several characteristics.

Presumably, both men and women will have increased utility from a marriage that results in childbirth. This particular benefit from marriage has lower odds of occurring as women age; therefore, unmarried women closer to the age at which the probability of pregnancy starts to decline may be more likely to intermarry.

Time spent in the US and the age at which an individual migrated to the US both affect levels of human capital. There are many types of investments in human capital; such investments could be education, language, training in certain occupations or industries, or investments in knowledge of and participation in aspects of a country’s 
culture. ${ }^{7}$ The relationship between ethnic and US-specific human capital will determine the rate of acquisition and also how individual stocks of human capital are retained. Age at migration is used as a proxy for the speed at which an individual may acquire USspecific human capital. Those who migrate at younger ages are likely to acquire USspecific human capital at a faster rate than those that migrate at older ages. Language, customs and traditions can be more easily acquired the younger the age at migration. Consider that children who learn a foreign language after the age of 6 are more likely to develop an accent (Asher 1969). Chisiwick and Miller (2008) show the decline in English language proficiency with a greater age at migration, other variables the same.

Chiswick (2006) provides a theoretical model that evaluates the association between ethnic and US-specific human capital and the corresponding impact on intermarriage. The rate of acquisition ultimately affects the stock of US-specific human capital which may alter preferences for intermarriage, depending on the relationship between ethnic and US-specific human capital. US-specific and ethnic human capital may be acquired in a complementary learning process (Chiswick, 2006). If the acquisition of US-specific human capital also increases the level of ethnic human capital, then ethnic and US-specific human capital have positive externalities (they are acquired in a complementary learning process). For example, a Japanese child will learn English in school and may speak Japanese with his parents at home. If learning English also improves his Japanese, then the two types of human capital (US-specific and ethnic) are acquired in a complementary learning process.

If the acquisition of US-specific human capital has positive externalities, then those that migrated as children and those that migrated as adults will both have relatively high levels of ethnic human capital, implying a high marginal benefit from ethnic compatibility. Assortative models of marriage indicate that high levels of ethnic-specific human capital will decrease the probability of intermarriage. High levels of ethnicspecific human capital imply some preference for ethnic goods, and marriage to a partner with similar levels of ethnic-specific human capital will insure that the acquisition of these goods is less costly. If there are positive externalities there should be little

\footnotetext{
${ }^{7}$ The acquisition of human capital relevant for the host country (US-specific human capital) need not necessarily imply an eroding of the individual's ethnic-specific human capital.
} 
difference between the probability of intermarriage between individuals that migrated as children and those that migrated as adults.

Conversely, if ethnic and US-specific human capital are anti-complementary in the development of knowledge, then these two types of human capital would compete for resources (including time) within an individual, indicating that high levels of US-specific human capital will be accompanied by low levels of ethnic human capital, and vice versa. A child fully engaged in American customs and traditions would be less inclined to participate in ethnic-specific customs and traditions. Consequently, individuals that migrate as children are less likely to have high levels of ethnic human capital. Thus, they have a lower marginal benefit of ethnic compatibility, raising the probability of intermarriage.

Figure 1 above captures this relationship, assuming $M C_{0}$ for all individuals . The two marginal benefit curves represent those that migrated as children $\left(M B_{0}\right)$, young adults $\left(M B_{1}\right)$ and adults $\left(M B_{2}\right)$. If general and ethnic human capital are acquired in an anti-complementary learning process, individuals that migrated as children would have the least marginal benefit from ethnic compatibility, while those who migrated as young adults will have a lower marginal benefit for ethnic compatibility $\left(M B_{0}\right)$ than those that migrated at older ages $\left(M B_{2}\right)$.

The amount of time an individual has been living in the US and the speed at which human capital is acquired provides a second link between age and ethnic human capital. Duration is important since human capital increases as time spent in the host country rises. The rate at which ethnic human capital is attained depends on the relationship between ethnic and US-specific human capital. Similar to that explained above, Chiswick’s (2006) model of ethnic human capital and assimilation is used to discuss the possible effects on the probability of intermarriage.

Because time is limited, time spent acquiring US-specific human capital means less time for the acquisition of ethnic human capital. If there are positive externalities between the acquisition of ethnic and US-specific human capital, then length of residence in the US will have little to no effect on the marginal benefit of ethnic compatibility. Therefore, an individual residing in the US for 5 years will have the same probability of intermarriage as an individual residing in the US for 10 years, ceteris paribus. 
If ethnic and US-specific human capital are anti-complementary in the development of knowledge, then high levels of US-specific human capital will generally be accompanied by low levels of ethnic human capital, and vice versa. Consider an individual enrolled in a time intensive course of study in the host country. Most likely he or she will have less time to engage in ethnic related activities, and therefore have lower levels of ethnic human capital than his/her un-enrolled counterparts. This anticomplementary relationship implies that individuals residing in the US for longer periods of time are more likely to be intermarried because of the acquisition of general (USspecific) human capital and the depreciation of ethnic human capital.

Other individual characteristics affecting the probability of intermarriage include previous marriages, the ethnic mix of the parental unit, gender and race. Potential partners may view a previous divorce as a signal of undesirable characteristics. Individuals with this trait will generate fewer marriage offers, and, therefore, have higher marginal cost of search. In addition, ties to the parental home are weaker if an individual has been married, and, therefore, the individual may have a lower marginal benefit of ethnic compatibility, increasing the probability of intermarriage.

Parents may affect choice of spouse, even if their wishes are not verbalized or even indirectly implied. Using information on ancestry, a proxy for intermarried parentage can be made. If the respondent lists multiple ancestries, it is assumed they come from an intermarried background. An individual from single ethnic parentage may have preferences for a potential partner of the same ethnicity, while this preference is less likely to be present among those with an intermarried background (lower marginal benefit from search). In addition, potential marriage partners from an ethnic group may view a person of mixed parentage, partly from that group and partly from another, as being less ethnically compatible. If mixed parentage is used as a signal of lower ethnic compatibility, then the marginal cost of search for a potential partner of either ethnic group will increase. Thus, children from intermarried parents will have a lower marginal benefit and higher marginal cost of search for a partner of the same ethnicity, and therefore a higher probability of intermarriage (i.e., marriage to a person whose ethnicity differs from that of either parent) than those from the same ethnic parentage.

The gender of the respondent is included to examine differences in the probability of intermarriage by gender. Immigrant women who marry in the US (post migration) 
may be more tied to the family home, and therefore have a higher marginal benefit of ethnic compatibility than immigrant males. Immigrant groups may differ in their attitudes toward males and females dating and marrying outside their ethnic groups.

\section{B. Marriage Market Characteristics}

Marriage market variables give an estimate of the respondent's pool of potential mates at the time of consideration of marriage. Four aspects with regard to the marriage market are considered: availability of potential partners of the same ethnicity and relevant age group, group size, modal education of the individual's ethnic group and relevant sex, and a measure of linguistic distance, the "distance” between English and the person's mother tongue.

Following Goldman et al. (1984), with some minor alterations, the availability ratio is specified by ethnicity and by geographic region, giving the following "availability ratio" for females $\left({ }^{F} A R_{i j k}\right)$ :

$$
{ }^{F} A R_{i j k}=\frac{\sum_{i}^{i+10} M_{i j k}}{\sum_{i-2}^{i+8} F_{i j k}}
$$

$M_{i j k}$ is the number of men of age $i$, in region $j$ from ethnic group $k . F_{i j k}$ is the number of women in the age group "competing" for the men in the numerator, in region, $j$, of race/ethnicity, $k .^{8}$ For example, the appropriate sex ratio for a white female age 20, is the number of white men aged 20-30 divided by the number of white females, aged 1828. Marriages tend to occur where the male partner is on average two years older than the female and following Goldman et al. (1984) the availability ratio is constructed to reflect this fact. The relevant cohort group will span a total of 11 years. Fossett and Kiecolt (1991) provide support for using broad age groups, finding that constricting age groups can overly restrict comparisons by age and ignore possible competition in close

${ }^{8}$ For men the ratio is ${ }^{M} A R_{i j k}=\frac{\sum_{i-2}^{i+8} F_{i j k}}{\sum_{i}^{i+10} M_{i j k}}$ 
cohorts. $^{9}$ In the absence of information on where they lived at the time, the individual's current location is assumed to be the same as when they were in the marriage market.

Using several Censuses to construct availability ratios will provide a more accurate portrayal of actual marriage markets according to specifications discussed in Section IV. As an individual's availability ratio increases, the marginal cost of ethnic compatibility decreases, and the probability of intermarriage decreases.

The availability ratio measures possible inequalities in the marriage market for men and women by taking into account competition by members of the same sex. Another important characteristic of the relative ethnic marriage market is the absolute size of the ethnic group. Group size measures the number of the opposite sex in a specific ethnicity or race by geographic region and age group. While the availability ratio may be close to one, indicating a relatively "balanced" marriage market, the actual number of the opposite sex in one's group would still be relevant as finding a "good match” within one's ethnic group increases with the size of the group. Thus, as an individual's group size increases, the marginal cost of search decreases and the probability of intermarriage decreases.

The size of the total population in the relevant age group for the time at which the individual was most likely in the marriage market is included to measure the size of the non-ethnic-specific marriage market. Intermarriage is more likely for those living in an area with a larger total population, controlling for their group size and availability rato.

Linguistic distance refers to the extent that languages differ from one another. The US Department of State, School of Language Studies teaches English-speaking Americans foreign languages and then assesses the proficiency in these languages. A paper by Hart-Gonzalez and Lindemann (1993) reports these scores for 43 languages. Chiswick and Miller (1998 and 2005) convert these scores into a measure of linguistic distance from English for nearly all of the languages (except Native American or American Indian languages) coded in the US Census PUMS file. A lower score corresponds to a greater distance between the foreign language and English. They find that lower levels of linguistic distance are associated with higher levels of English

\footnotetext{
${ }^{9}$ Fossett and Kiecolt (1991) point out that there is a structure of preference within the broad age ranges and suggest using weights. While this appears to be useful, Goldman, Westoff and Hammerslough (1984) have found weighted and un-weighted sex ratios to be statistically similar. In addition, assigning weights to particular age groups would be rather arbitrary, as personal preferences vary.
} 
fluency. Linguistic distance can be used to predict the probability of intermarriage, as those with the potential for greater English ability are more likely to have lower costs and greater benefits from intermarriage. A greater distance between the individual's foreign language and English will result in a lower probability of intermarriage.

\section{Education and Veteran Status}

As mentioned in the literature review above, the effect that education has on the probability of intermarriage is threefold. Years of education is included to test for these relationships. First, education may affect an individual's preferences for ethnic compatibility. Highly educated individuals may have a lower marginal benefit of search for a partner of the same ethnicity and, hence, are more likely to be intermarried than those with lower educational levels. Second, education may alter an individual's marriage market because individuals may be more likely to move out of their ethnic enclave and family influences when attending college. This effect can not be measured directly, as the data do not provide a direct measure or proxy for individuals who are likely to move out of an ethnic enclave, but schooling level serves as a proxy.

Another avenue through which education may alter the probability of intermarriage depends on preferences for education levels of a spouse and changes in the relevant marriage market. Specifically, education levels may be used, in addition to ethnicity, as a trait with which individuals match up. Education can be used to signal possible compatibility. Positive assortative mating implies that individuals with high levels of education, in ethnic groups with relatively low levels of education, are more likely to be intermarried because of a thinner marriage market for their ethnic group within their educational level. Similarly, individuals with low levels of education, in groups with relatively high levels of education, are more likely to be intermarried.

Although most studies use average levels of education, this study uses modal education levels. Modal values may provide a better measure of central tendency to make comparisons across ethnic groups. For example, the majority of immigrants in the sample have education levels above the $6^{\text {th }}$ grade, while only a small percentage have more than a bachelor's degree. Therefore, for small ethnic groups, a few individuals with high levels of education can skew the average to overestimate the "typical" education level of the ethnic group. The modal education levels by ethnic/racial groups will be 
taken from the relevant Census and will be determined by the same age groupings as used in construction of group size.

Those in the US military may be more likely to marry outside their ethnicity than non-veterans because of separation from one’s parents and ethnic community, and exposure to a broader range of ethnic groups within the military and members of other ethnic groups in the local community in postings in the US and overseas. The pertinent ethnic marriage market may be virtually non- existent for those overseas, which increases the marginal cost of search for ethnic compatibility. In addition, men based overseas are exposed to a different culture and may have a higher marginal benefit for intermarriage and, consequently, a lower marginal benefit of ethnic compatibility. Both the increase in marginal cost and the decrease in marginal benefit will decrease the level of ethnic compatibility and, therefore, will increase the probability of intermarriage. The probability of intermarriage may vary by period of time of military service.

\section{Data and Estimating Equation}

The US 1980 Census of Population and Housing, Public Use Microdata Sample (B-Sample) 1\% Sample (PUMS) is used to address the determinants of ethnic intermarriage among immigrants. The 1980 Census is specifically used because it includes "age at first marriage”, a question that has not been included in more recent Censuses. The questions, “age at first marriage” and "migration year” are used to determine whether the individual's first marriage took place after immigration, permitting examination of an immigrant's decision to marry outside of his/her ethnicity in the US. Many of the characteristics of the US marriage market are not relevant for immigrants married prior to migration, therefore, the sample is restricted to individuals married after migration. It is important to note that the Census data only give information on spouses that exist at the time of the Census. Thus only those currently married and living with their spouse can be studied.

The dependent variable is dichotomous and equal to one if the respondent is currently married to an individual of a different ethnicity and is used as a measure of intermarriage. Two proxies are used for ethnicity: ancestry and country of birth. Under

the ancestry definition, immigrants are considered to be intermarried if their spouse is of a different ancestry, without regard for country of birth. When multiple ancestries are reported in response to the Census question, the first response is taken as the person's 
ethnicity. ${ }^{10}$ Under the country of birth definition, immigrants are considered to be intermarried if their spouse was born in a different country, including the United States.

To test the hypotheses developed above for immigrants, the following equation is run with both sexes and also separately by gender for both definitions of ethnicity.

$\ln [$ P(INTRMAR $=1) / P($ INTRMAR $=0)]=\mathrm{b}_{0}+\mathrm{b}_{1} \mathrm{SEX}+\mathrm{b}_{2}$ GRADE $+\mathrm{b}_{3}$ GRADE2 $+\mathrm{b}_{4}$ DEVMODE $+\mathrm{b}_{5}$ TIMESMAR+

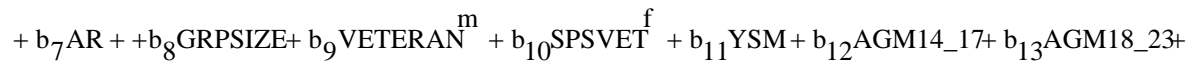

$\mathrm{b}_{14}$ AGM24_28+ $\mathrm{b}_{15}$ AGM29_35+ $\mathrm{b}_{16}$ AGM36_+ $\mathrm{b}_{17}$ MULTANG $\mathrm{b}_{18}$ AGMAR31_45 $\mathrm{b}_{19}$ AGMAR64_+ $\mathrm{b}_{20}$ RACE $+\mathrm{b}_{21}$ LINGDIS

$+\mathrm{b}_{22}$ ENGONLY+ $\mathrm{b}_{22} \mathrm{POP}$

Where SEX is a dichotomous variable equal to 0 if the respondent is male and 1 if female. TIMESMAR is a dichotomous variable equal to 0 if married once and equal to 1 if married more than once. To test the effect that later marriages may have on the probability of intermarriage two dichotomous variables are included, AGMAR31_45 and AGMAR64_are constructed and equal to one if the respondent was married in the age ranges listed. AGMAR18_30 is the benchmark group.

For the period under study, the decades prior to 1980 , the military was composed primarily of males. Thus, the veteran variable is defined only for males, while the variable for the spouse of a veteran is defined only for females. The veteran variable is defined as follows: VET75 is equal to 1 if the respondent served in the US military in May 1975 or later and equal to 0 otherwise. VETVIET is equal to 1 if the respondent served in the military during the Vietnam War (August 1964- April 1975) and equal to 0 otherwise. VET55_64 is equal to 1 if the respondent served in the military between February 1955 and July 1964 and equal to 0 otherwise. VETKOR is equal to 1 if the respondent served in the military during the Korean Conflict (June 1950-January 1955) and equal to 0 otherwise. VETWWII is equal to 1 if the respondent served in the military during WWII (September 1940-July 1947) and equal to 0 otherwise. VETOTHER is

\footnotetext{
${ }^{10}$ Table A-1 in the Appendix includes a list of these ethnicities and their components. Table A-2 in the Appendix includes a list of countries of birth which are used as the second proxy for ethnicity. Tables A-3 and A-4 in the Appendix show intermarriage rates among immigrants where ethnicity is defined by ancestry and country of birth, respectively. Only eight percent of the sample reports a multiple ancestry for the 1980 Census data.
} 
equal to one if the respondent served in the military at any other time. SPSVET is a dichotomous variable equal to one if the respondent's spouse served in the US military.

The availability ratio, AR, is as specified in Section III and is taken from the relevant marriage market Census. The relevant marriage market for an individual is more accurately estimated at the time during which they were most likely to have been "in the market”. Because the Census survey data are collected every 10 years, a good estimate for a female aged 30 in 1980 is information on the population she potentially encountered at age 20: characteristics for men aged 20-30 taken from the 1970 Census. Given the limitations in the Census data, it is assumed the individual lived in the same location in 1980 and the year for which the marriage market variables are taken.

Thus, marriage market variables are extracted in the following manner: Group 1Marriage market variables for 18-27 year olds are estimated with the 1980 Census. Group 2- Marriage market variables for 28-45 year olds are estimated with the 1970 Census. Group 3- Marriage market variables for 46-64 year olds are estimated with the 1960 Census.

Group size, GRPSIZE, is a variable equal to the number of the opposite sex (in thousands) estimated for the respondent's ethnic group and region. Group size is estimated separately for ethnicity defined by ancestry and country of birth. GRPSIZE for Group 1 (using the 1980 Census) is estimated from the number of individuals aged 18-35 by geographic region and ethnicity. GRPSIZE for Group 2 (using the 1970 Census) is estimated from the number of individuals aged 18-35 by geographic region and ethnicity. GRPSIZE for Group 3 (using the 1960 Census) is estimated from the number of individuals aged 28-45 by geographic region and ethnicity. Population is measured by region and uses the same age ranges as GRPSIZE, but includes the total population, regardless of ethnicity.

Location is defined by SMSA for data from the 1980 and 1970 Censuses and state for the 1960 Census. The 1960 Census does not provide information on SMSA. An SMSA is defined as an area of 100,000 or more. Many large cities, groups of cities and counties are defined within large SMSA's.

GRADE represents years of education. GRADE2 is GRADE squared. To test the theory of positive assortative mating, two variables equal to the deviation of the modal education level of the group are included. In the above equation DEVMODE represents 
two possible variables. HIGHL is equal to the deviation from the mode if the respondent has an education level higher than the mode of the ethnic group. LOWHI is equal to the deviation from the mode if the respondent has an education level lower than the mode of the ethnic group. Education modes for the ethnic group are estimated by ethnic group, geographic region and age group. In addition, education modes are estimated separately by ethnicity defined by ancestry and country of birth.

To test the effect that age at immigration has on the probability of intermarriage immigrants are divided into 5 groups, each represented by a dichotomous variable. The dichotomous variable is equal to one if the respondent's age at immigration is in the particular age group. The variables are labeled AGMXXX, where XXX refers to the age group. The 1980 Census gives information on immigration year in. By using a midpoint of the migration intervals and the individual's exact age, a variable representing the age at immigration is constructed.

Individuals that migrated as children are the benchmark group and range in age from 0 to 13 (AGM0_13). Teenagers are classified as having immigrated between the ages of 14 and 17 (AGM14_17) and young adults as between the ages of 18 to 23 (AGM18_23). Adults are divided into three groups: those who migrated between the ages of 24 and 28 (twenties) (AGM24_28), the ages of 29 and 35 (thirties) (AGM29_35), and those who migrated at age 36 or after (older immigrants) (AGM36).

LINGDISXXX represents eight dichotomous variables for each level of linguistic distance, where $\mathrm{XXX}$ is equal to the value of linguistic distance. For example, a value of 1 represents languages the furthest from English. The benchmark are individuals from native English speaking countries.

The effect that duration in the US has on the probability of endogamy can be estimated using years since migration, YSM. MULTANC is a dichotomous variable equal to 1 if the respondent lists multiple ancestries, thereby implying parental intermarriage, and 0 if only one ancestry is listed. Dichotomous variables indicating race are included. These include WHITE, non-Hispanic, as the benchmark group, BLACK (non-Hispanic), AMINDIAN (American Indian), ASIAN, HISPANIC, ASINDIAN (South Asian) and OTHER. 


\section{Empirical Results}

\section{A. Pooled Across Gender}

Results of the logistic regression using the 1980 Census are shown in Tables 1 and 2 for the pooled sample of immigrant women and men, separately estimated for ethnicity defined by ancestry and country of birth, respectively. The signs of the coefficients are similar regardless of the definition of ethnicity, although they are stronger when ethnicity is defined by country of birth. In addition, the overall explanatory power of the equation is more robust when ethnicity is defined by country of birth. This pattern is generally shown throughout. 
Table 1

Logistic Regression Estimates of Intermarriage for Immigrants with Ethnicity Defined by Ancestry

Dependent Variable: Intermarriage

Pooled Sample Size $=29,137 \quad$ Pseudo R2 $=.1008$

\begin{tabular}{|c|c|c|c|c|c|c|}
\hline Variable & Coeff & z-score & $\mathrm{dy} / \mathrm{dx} \mathrm{x}^{\mathrm{a}}$ & z-score & $\mathbf{X}$ & Odds Ratio \\
\hline OTHER* & 0.02 & 0.19 & 0.005 & 0.19 & 0.02 & 1.02 \\
\hline BLACK* & -0.45 & -7.03 & -0.111 & -7.23 & 0.05 & 0.64 \\
\hline AMINDIAN* & -0.03 & -0.09 & -0.006 & -0.09 & 0.00 & 0.97 \\
\hline ASIAN* & -0.42 & -10.37 & -0.105 & -10.57 & 0.13 & 0.66 \\
\hline ASINDIAN* & -1.01 & -10.82 & -0.235 & -12.62 & 0.02 & 0.36 \\
\hline SPAN* & -0.18 & -3.9 & -0.045 & -3.92 & 0.10 & 0.84 \\
\hline AGMAR31_45* & 0.18 & 4.2 & 0.045 & 4.2 & 0.127 & 1.2 \\
\hline AGMAR64_* & 0.30 & 2.08 & 0.075 & 2.08 & 0.008 & 1.36 \\
\hline TIMESMAR* & 0.81 & 17.83 & 0.195 & 19.3 & 0.10 & 2.25 \\
\hline HIGHL4 & 0.01 & 1.77 & 0.002 & 1.77 & 3.85 & 1.01 \\
\hline LOWHI4 & 0.04 & 5.06 & 0.009 & 5.06 & 1.66 & 1.04 \\
\hline GRADE & 0.13 & 10.56 & 0.032 & 10.56 & 11.73 & 1.14 \\
\hline GRADE2 & -0.0005 & -4.79 & -0.001 & -4.79 & 158.41 & 1.00 \\
\hline GRPSIZE4 $^{\mathrm{b}}$ & -0.13 & -16.87 & -0.032 & -16.87 & 0.88 & 0.88 \\
\hline AR4 & -0.43 & -8.98 & -0.108 & -8.98 & 0.75 & 0.65 \\
\hline POP & 0.00 & 8.06 & 0.001 & 8.06 & 49.26 & 1.00 \\
\hline AM14_17* & -0.35 & -7.26 & -0.087 & -7.37 & 0.12 & 0.70 \\
\hline AM18_23* & -0.33 & -7.99 & -0.081 & -8.04 & 0.30 & 0.72 \\
\hline AM24_28* & -0.36 & -8.14 & -0.090 & -8.22 & 0.23 & 0.70 \\
\hline AM29_35* & -0.30 & -5.7 & -0.075 & -5.75 & 0.13 & 0.74 \\
\hline AM36_* & -0.28 & -3.18 & -0.070 & -3.22 & 0.04 & 0.75 \\
\hline YSM & 0.0007 & 1.65 & 0.001 & 1.65 & 16.88 & 1.00 \\
\hline MULTANC* & 0.39 & 7.79 & 0.097 & 7.95 & 0.08 & 1.48 \\
\hline SPSVET* & 1.12 & 29.75 & 0.266 & 32.88 & 0.21 & 3.06 \\
\hline SEX* & -0.22 & -7.37 & -0.055 & -7.38 & 0.53 & 0.80 \\
\hline _cons & -0.87 & -7.56 & & & -0.64 & \\
\hline
\end{tabular}

${ }^{a} \mathrm{dy} / \mathrm{dx}=\operatorname{Pr}(\mathrm{INTRMR})($ predict $)$ - marginal effects are the partial derivative with respect to $\mathrm{X}$ (mean) of the probability of intermarriage, where $\mathrm{X}$ is specified at the mean, except for dummy variables $(*)$. The marginal effect for a dichotomous variable is the discrete change from 0 to 1.

${ }^{\mathrm{b}}$ GRPSIZE and POP are in thousands

${ }^{\mathrm{c}}$ The benchmark group for AM variables are individuals that migrated prior to age 14 .

Source: 1960 to 1980 Censuses of Population, Public Use Microdata Samples 
TABLE 2

\section{Logistic Regression Estimates of Intermarriage for Immigrants with Ethnicity Defined by Country of Birth Dependent Variable: Intermarriage}

\begin{tabular}{|c|c|c|c|c|c|c|}
\hline Pooled & Sample Siz & $=29,137$ & & seudo R2 & $=.1728$ & \\
\hline Variable & Coeff & z-score & $\mathrm{dy} / \mathrm{dx}$ & z-score & $\mathbf{X}$ & $\begin{array}{l}\text { Odds } \\
\text { Ratio }\end{array}$ \\
\hline OTHER* & 0.15 & 1.45 & 0.029 & 1.5 & 0.02 & 1.16 \\
\hline BLACK* & -0.78 & -10.98 & -0.176 & -10.18 & 0.05 & 0.46 \\
\hline AMINDIAN* & 0.17 & 0.5 & 0.032 & 0.52 & 0.00 & 1.18 \\
\hline ASIAN* & -0.75 & -17.07 & -0.167 & -15.97 & 0.13 & 0.47 \\
\hline ASINDIAN* & -0.91 & -9.65 & -0.209 & -8.94 & 0.02 & 0.40 \\
\hline HISPANIC* & -0.06 & -1.26 & -0.012 & -1.25 & 0.10 & 0.94 \\
\hline AGMAR31_45* & -0.36 & -7.74 & -0.076 & -8.39 & 0.13 & 0.69 \\
\hline AGMAR64_* & -0.53 & -3.38 & -0.117 & -3.76 & 0.008 & 0.59 \\
\hline TIMESMAR* & 1.16 & 17.91 & 0.182 & 24.79 & 0.10 & 3.19 \\
\hline HIGHL & 0.01 & 2.43 & 0.002 & 2.43 & 3.62 & 1.01 \\
\hline LOWHI & 0.003 & 0.4 & 0.001 & 0.4 & 1.51 & 1.00 \\
\hline GRADE & 0.04 & 3.35 & 0.007 & 3.35 & 11.73 & 1.04 \\
\hline GRADE2 & -0.00008 & -0.18 & -0.00002 & -0.18 & 158.41 & 1.00 \\
\hline GRPSIZE & -0.05 & -6.89 & -0.010 & -6.89 & 0.81 & 0.95 \\
\hline AR & -0.31 & -5.73 & -0.063 & -5.73 & 0.78 & 0.73 \\
\hline POP & 0.0005 & 1.72 & 0.0001 & 1.72 & 49.26 & 1.00 \\
\hline AM14_17* & -0.55 & -10.48 & -0.120 & -9.83 & 0.12 & 0.58 \\
\hline AM18_23* & -0.43 & -9.43 & -0.089 & -9.15 & 0.30 & 0.65 \\
\hline AM24_28* & -0.24 & -4.84 & -0.050 & -4.71 & 0.23 & 0.79 \\
\hline AM29_35* & 0.23 & 3.63 & 0.044 & 3.78 & 0.13 & 1.25 \\
\hline AM36_* & 0.76 & 7.34 & 0.127 & 9.16 & 0.04 & 2.13 \\
\hline YSM & 0.04 & 21.34 & 0.008 & 21.37 & 16.88 & 1.04 \\
\hline MULTANC* & 0.80 & 11.45 & 0.134 & 14.21 & 0.08 & 2.21 \\
\hline SPSVET* & 1.97 & 38.03 & 0.293 & 56.99 & 0.21 & 7.16 \\
\hline SEX* & -0.38 & -12.22 & -0.076 & -12.28 & 0.53 & 0.68 \\
\hline _cons & -0.02 & -0.2 & & & 0.19 & \\
\hline
\end{tabular}

Notes: See Notes to Table 1.

Source: 1960 to 1980 Censuses of Population, Public Use Microdata Samples

In the United States, ethnic and US-specific human capital do compete for space within an individual and are not overall complements in the learning process. The coefficients on the age at migration variables are significant and negative for AM14_17, AM18_23 and AM24_28, indicating that these groups are less likely to intermarry than those that migrated before the age of 13 , regardless of which of the two definitions of ethnicity is used. Further support that ethnic and US-specific human capital are not 
overall complements in the learning process can be seen through the variable years since migration. Each year spent in the US, measured by YSM, increases the probability of intermarriage by .1\% when intermarriage is defined by ancestry and $.8 \%$ when intermarriage is defined by country of birth. An individual that has been living in the US for 30 years is $16 \%$ more likely to marry someone from a different country than an individual that has been living in the US for 10 years, all else equal.

Immigrant women (whose first marriage is after migration) are significantly less likely to be intermarried than immigrant men for both definitions of ethnicity. The odds of intermarriage decrease by $20 \%$ if the respondent is female when ethnicity is defined by ancestry and by $32 \%$ when ethnicity is defined by country of birth. A possible implication of the gender difference is that immigrant women are more tied to the family home. The rules of dating may be stricter for females and they may have less opportunity to socialize with individuals outside of their ethnicity. Alternatively, immigrant females may have stronger preferences for endogamy than immigrant males as they have the larger role in the raising of children.

Individuals who have been married more than once (TIMESMAR) have a higher probability of the current marriage being an interethnic marriage. Previous marriages may be seen as a signal of other unmeasured undesirable characteristics, or that a previous marriage has weakened ties to family and ethnic community. The Census contains information on age at first marriage, but if an individual has been married more than once, the relevant variable for this estimation is age at current marriage which is not available. Those that have been married more than once are likely to be in a marriage that took place at an "older" age than age at first marriage. Therefore, they faced a smaller ethnic marriage market when searching for their current spouse and have a higher probability of intermarriage. An individual who has been married more than once has a $125 \%$ increase in the odds of being intermarried compared to individuals in their first marriage when ancestry is used to define ethnicity. The effect is stronger (219\%) when country of birth is used to define ethnicity.

The availability ratio, group size, and total population variables capture the best estimate of an individual's ethnic marriage market. The availability ratio shows that an increase in the number of members of the opposite sex in an individual's ethnic group 
relative to the number of members of the respondent's own sex decreases the probability of intermarriage.

The coefficient on group size implies a decrease in the likelihood of intermarriage when ethnicity is defined by ancestry. As the absolute size of the pool of potential partners increases, immigrants are less likely to marry outside of their ancestry. The effect of group size is slightly smaller when ethnicity is defined by country of birth. Ethnic enclaves develop as a way to efficiently engage in ethnic related behavior, such as food preparation, celebration of holidays, and dress. They are likely to include individuals from different countries that share similar ancestries (e.g., Hispanics). Therefore, individuals who reside in ethnic enclaves have a larger ethnic marriage market by ancestry and are more likely to marry within their ancestry than to someone from their country of birth.

A person with intermarried parents is $48 \%$ more likely to be intermarried when intermarriage is defined by ancestry and $121 \%$ more likely when intermarriage is defined by country of birth. Individuals with intermarried parents are less likely to marry a person of either ethnicity of their parents' than are those with a single ancestry (endogomously married parents). Immigrants with parents who are from different countries are three times more likely to be intermarried than those with parents of different ancestries.

GRADE is positively related to intermarriage. GRADE2 has a negative coefficient, indicating that as educational levels increase the probability of intermarriage increases, at a decreasing rate. The partial effect of GRADE is never negative, indicating that increases in education will always increase the probability of intermarriage. Education may alter preferences for ethnic compatibility or move individuals out of ethnic enclaves. Table 3 below shows the marginal effects of each year of education on the probability of intermarriage for immigrants. 
Table 3

Marginal Effect of Years of Schooling Completed on the Probability of Intermarriage when Intermarriage is defined by Ancestry $^{11}$

Pooled Sample: US Immigrants (1980 US Census Data)

\begin{tabular}{rrr}
\hline $\begin{array}{c}\text { Year of } \\
\text { Schooling }\end{array}$ & dy/dx & z-score \\
\hline 3 & 0.021 & 65.6 \\
4 & 0.020 & 38.07 \\
5 & 0.024 & 26.83 \\
6 & 0.026 & 20.97 \\
7 & 0.027 & 17.47 \\
8 & 0.029 & 15.19 \\
9 & 0.030 & 13.65 \\
10 & 0.030 & 12.59 \\
11 & 0.032 & 11.87 \\
12 & 0.032 & 11.41 \\
13 & 0.033 & 11.17 \\
14 & 0.033 & 11.11 \\
15 & 0.033 & 11.26 \\
16 & 0.032 & 11.61 \\
17 & 0.031 & 12.2 \\
18 & 0.030 & 13.08 \\
19 & 0.029 & 14.37 \\
20 & 0.027 & 16.24 \\
\hline
\end{tabular}

Source: 1980 Census of Population, Public Use Microdata Samples

When ethnicity is defined by ancestry, the variables HIGHL and LOWHI are both significant and positive. Individuals who have education levels at least one year above or at least one year below the mode of their group are more likely to intermarry, indicative of positive assortative theories of marriage. In this case, individuals trade off ethnicity for more compatible levels of education in their spouse. Individuals with high levels of education in groups with lower modal levels of education (HIGHL) have a harder time finding someone within their education level to marry. When ethnicity is defined by country of birth, only HIGHL is significant.

Race is included to examine whether patterns of intermarriage by immigrants vary by race. Races include white, black, American Indian, Asian Indian, Asian, Hispanic and

\footnotetext{
11 The marginal effect of years of schooling is calculated at each specified year of schooling, controlling for all other variables.
} 
Other. It is recognized that Hispanic is not a separate racial group. However, individuals within this group are likely to have broadly similar geographic and cultural origins and to speak Spanish. Black, Asian, Asian Indian and Hispanic immigrants are less likely to intermarry than whites (Tables 1 and 2). One possible explanation is that the majority of the US population is white and there is a tendency for racial groups in the US to be largely endogamous in terms of marriage. Therefore, it is more likely for a white immigrant to marry a white native born or immigrant of a different ancestry or country of origin than immigrants of other racial groups.

The first major difference between the results for the alternate definitions of ethnicity relates to those who migrated to the US as adults. When ethnicity is defined by country of birth, AM29_35 and AM36_have coefficients that are positive and statistically significant, but when ethnicity is defined by ancestry the coefficients are statistically significant and negative. Individuals who migrate at older ages are more likely to marry outside their country of origin than individuals that migrate as children, but are less likely to marry outside of their ancestry group. That is, they are more likely to marry individuals with a similar ancestry but from a different country of birth.

Those who migrated past the age of 28, who married within their ancestry group and to individuals from other countries are mainly: English, Scottish, French, German, Greek, Irish, Italian, Polish, Spanish, Mexican, Chinese, Filipino, Japanese and Korean. For European ancestries, the majority of the individuals were either born in the country associated with that ancestry, or in Canada. For example, persons of German ancestry born in Canada who migrated to the US at later ages are more likely to marry nonCanadians, but are more likely than Germans that migrated to the US as children to marry persons of German ancestry. Perhaps those of German ancestry born in Canada over age 28 have a greater attachment to their ancestry than Germans who migrated to the US before the age of thirteen.

Individuals with Spanish ancestry were most likely born in Mexico, Cuba or Spain. Individuals that migrated from Cuba at later ages are less likely to marry Cubans than those that migrated as children, but are more likely to marry individuals born in Mexico or Spain. Those that marry at older ages may lower their "reservation price”, in this case choose to accept a spouse not born in Cuba. At the same time, because they migrate at later ages they have less destination specific human capital, which is valued in 
the marriage market for the native born and foreign born that migrated at young ages. They are less picky, but also are more constrained by low levels of destination specific human capital, namely English language skills. Therefore, they accept marriage offers outside of their country of birth, but must find a spouse who speaks Spanish.

The definition of ethnicity also produces differing coefficients on the age at first marriage variables. For ethnicity defined by birthplace, individuals who marry between the ages of 31 and 45 have a 1\% decrease in the odds of intermarriage compared to those who married before the age of 31. When ethnicity is defined by ancestry, individuals that marry between the ages of 31 and 45 have a 1\% increase in the odds of being intermarried. Thus, older marriages tend to involve mates from the same country of origin (same language) but different ancestry groups.

Odds ratios for the linguistic distance variables are presented in Table 4 for the pooled sample of immigrant women and men, separately estimated for ethnicity defined by ancestry and country of birth. LING1 represents languages furthest away from English, mainly made up of Korean and Japanese, LING3 are those closest to English, such as Swedish. The benchmark are those who come from English speaking countries. The patterns are consistent for both definitions of ethnicity, with the exception of LING1. For instance, Table 3 shows that for those who speak languages relatively far linguistically from English, LING175, are 60\% less likely to be intermarried than those who come from English speaking countries, whereas those that speak languages closer to English, LANG275, are only 32\% less likely to be intermarried. Interestingly, those who speak languages furthest from English, like Korean and Japanese, are more likely to be intermarried (based on ancestry) than those who come from English speaking countries. When the linguistic distance variables are examined separately by gender, it appears that this result is driven by females who speak Korean or Japanese and not males, suggesting that this represents a "war brides” effect. That is, Korean and Japanese women who married members of the US Armed Forces stationed in these countries. 
Table 4

Logistic Regression Estimates of Intermarriage for

Immigrants- Linguistic Distance

Source: 1980 US Census Data

Dependent Variable: Intermarriage

\begin{tabular}{lllllll}
\hline & \multicolumn{3}{c}{ Ancestry } & \multicolumn{3}{c}{ Country of Birth } \\
\hline Variable & All & Male & Female & All & Male & Female \\
\hline LING1 & $1.42^{*}$ & 0.76 & $1.59^{*}$ & $0.65^{*}$ & $0.42^{*}$ & $0.72^{*}$ \\
LING15 & $0.66^{*}$ & 0.80 & $0.51^{*}$ & $0.34^{*}$ & $0.48^{*}$ & $0.24^{*}$ \\
LING175 & $0.40^{*}$ & $0.57^{*}$ & $0.25^{*}$ & $0.27^{*}$ & $0.42^{*}$ & $0.18^{*}$ \\
LING2 & $0.88^{*}$ & 0.90 & $0.80^{*}$ & $0.38^{*}$ & $0.47^{*}$ & $0.29^{*}$ \\
LING225 & $0.68^{*}$ & $0.64^{*}$ & $0.72^{*}$ & $0.36^{*}$ & $0.41^{*}$ & $0.34^{*}$ \\
LING25 & $0.61^{*}$ & $0.55^{*}$ & $0.66^{*}$ & $0.35^{*}$ & $0.44^{*}$ & $0.28^{*}$ \\
LING275 & $0.68^{*}$ & 0.78 & $0.62^{*}$ & $0.43^{*}$ & $0.61^{*}$ & $0.31^{*}$ \\
LING3 & 0.89 & 0.70 & 1.16 & 0.75 & 0.80 & 0.78 \\
\hline
\end{tabular}

Note: Pooled Sample Size $=27,116$. Controlling for the other explanatory variables in Tables 1 and 2. Odds ratios reported in Table. * designates statistically significant at 5 percent level.

Source: 1960 to 1980 Censuses of Population, Public Use Microdata Samples.

\section{B. Separate Analyses by Gender}

Separate analyses are conducted by gender for the two definitions of ethnicity, regression results are reported in Appendix B.

GRADE and GRADE2 follow the same pattern as the pooled sample. As education levels increase, the probability of intermarriage increases, but at a decreasing rate. The coefficient on LOWHI (a person with a low education from a highly educated group) is significant, positive and of a similar magnitude for both men and women when ethnicity is defined by ancestry. This coefficient indicates that individuals with education levels below the modal education level of the group are more likely to intermarry. This result supports positive assortative mating models. Individuals with low education levels will find a smaller pool of potential mates, as most of the individuals in their ethnic group are of a higher education level and have been sorted with other highly educated individuals. When ethnicity is defined by country of birth, however, deviations from the mode are not significant. 
Veteran status is important for both men and women. Immigrant men who served in the U.S. armed forces are more likely to be intermarried than those who are not veterans, especially if this service was during WWII, when so many were stationed overseas, or was in 1975 to 1980 . Immigrant women with a spouse in the armed forces are almost 200\% more likely to be intermarried when intermarriage is defined by ancestry and 588\% when defined by country of birth. These variables account for the effect that "war brides" have on the probability of intermarriage, which is a stunningly large effect. Women have lower intermarriage rates than men, except for "war brides".

The age at migration variables for both men and women are significant and negative for almost all of the age groups. This relationship indicates that migrating before the age of 13 increases the probability of intermarriage, as individuals that migrated before age 13 are the benchmark group. When ethnicity is defined by the ancestry question, migrating past the age of 36 does not have a significant effect on the probability of intermarriage compared to the youngest age at migration group. When ethnicity is defined by country of birth, women who migrated past the age of 29 are more likely to be intermarried than those who migrated as children. As discussed above, this effect may be related to the types of individuals who migrate at later ages, those who marry within their ancestry group and to individuals from other countries. A large majority of those who marry within their ancestry group and outside their country of origin are from Canada.

Another interesting result is that race matters for both males and females, regardless of the definition of ethnicity. Immigrant blacks, Asians, Asian Indians, and Hispanic are all less likely to intermarry than immigrant whites, controlling for the "war brides” effect for immigrant women.

\section{Summary and Conclusions}

A number of results were obtained by examining the determinants of intermarriage for first generation immigrants using the 1980 US Census of Population and Housing, the last Census that included the question on age at first marriage. Ethnicity is defined by both ancestry and country of birth.

Ethnic intermarriage rates in the US are greater among whites than other racial groups, are greater for men than for women (except for “war brides”), decrease with the age at migration, and increase with educational attainment, duration of residence in the 
US, the disparity between one's own educational attainment and that of one's ethnic group, having had a pervious marriage, and if one’s parents were intermarried.

Intermarriage rates are higher for men who were veterans, and higher for women who are married to veterans. They are also greater the smaller the potential availability of a spouse of the same ethnicity, and the smaller the size of one's ethnic group, although the absolute population size where one lives has little effect.

This paper contributes to the literature in this area of study in several ways. First, several data sets (1960 to 1980 Censuses) are used to construct marriage market variables, specifically group size, population size and the availability ratio. This method provides a more accurate picture of marriage market characteristics. In addition, three variables are included to test for the relationship between education and intermarriage. By including both education level and deviations from the modal education level of the ethnic group, two possible venues are examined. There is evidence of both positive assortative mating and also an independent positive effect by education level. Finally, this paper provides an exogenous proxy for English language skill among immigrants. Because current English fluency is endogenously related to intermarriage, using a proxy, linguistic distance, can measure the effect indirectly. Intermarriage rates are lower the greater the distance between the immigrant's mother tongue and English. A noticeable "war brides" effect is found in the analysis in contrast to the generally lower intermarriage rate for women.

The lack of direct information on specific country of residence when education was completed, as well as information on the timing of the current marriage, hinders research on the determinants of intermarriage. In addition, the 1980 Census was the last time age at first marriage was asked. This information is imperative for examining the marital decisions of more recent immigrants in the United States. 


\section{References}

Alba, R. D., Golden, R. M.: Patterns of Ethnic Intermarriage in the United States. Social Forces 65:202-223, 1986.

Anderson, R. N., Saenz, R.: Structural Determinants of Mexican American Intermarriage, 1975-1980. Social Science Quarterly 75:414-430, 1994.

Asher, J. J.: The Optimal Age to Learn a Foreign Language. The Modern Language Journal 53:334-341, 1969.

Becker, G. S.: A Theory of Marriage. Economics of the Family Chicago/London: University of Chicago Press 299-344, 1974.

Brien, M. J.: Racial Differences in Marriage and the Role of Marriage Markets. Journal of Human Resources 32 (4): 741-78, 1997.

Buchanan, P. J.: State of Emergency: The Third World Invasion and Conquest of America. New York: Thomas Dunne Books/ St. Martin’s Press, 2006.

Chiswick, B. R.: The Effect of Americanization on Earnings of Foreign Born Men. The Journal of Political Economy 86: 897-921, 1978.

Chiswick, B. R. and Paul W. Miller: English Language Fluency Among Immigrants to the United States. Research in Labor Economics 17: 151-200, 1998.

Chiswick, B. R. and Paul W. Miller: Linguistic Distance: A Quantitative Measure of the Distance Between English and Other Languages. Journal of Multilingual and Multicultural Development 26: 1-11, 2005.

Chiswick, B. R. and Paul W. Miller: A Test of the Critical Period Hypothesis for language Learning. Journal of Multilingual and Multicultural Development, 29(1): 16-29, 2008.

Chiswick, C. U.: The Economic Determinants of Ethnic Assimilation. IZA - Institute for the Study of Labor, Discussion Paper No. 2212, Bonn, Germany, July 2006. Journal of Population Economics (Forthcoming).

Chiswick, C. U. and Lehrer, Evelyn L.: Religious Intermarriage: An Economic Perspective. Contemporary Jewry 12:21-34, 1991.

Cohen, S. M.: Socioeconomic Determinants of Intraethnic Marriage and Friendship. Social Forces 55(4):997-1010, 1977.

Fitzgerald, J.: Welfare Durations and the Marriage Market: Evidence from the Survey of Income and Program Participation. The Journal of Human Resources 26:545-561, 1991. 
Fossett, M. A., Kiecolt, K. J.: A Methodological Review of the Sex Ratio: Alternatives for Comparative Research. Journal of Marriage and the Family 53:941-957, 1991.

Furtado, D.: Human Capital and Interethnic Marriage Decisions. IZA - Institute for the Study of Labor, Discussion Paper Series No. 1989, Bonn, February 2006.

Gilbertson, G.A., Fitzpatrick, J.P., Yang, L.: Hispanic Intermarriage in New York City: New Evidence from 1991. International Migration Review 30: 445-459, 1996.

Goldman, N., Westoff, C. F., Hammerslough, C.: Demography of the Marriage Market in the United States. Population Index 50:5-25, 1984.

Gordon, M.: Assimilation and American Life: The Role of Race, Religion and National Origins Oxford University Press, Inc. 1964.

Hart-Gonzalez, L. and Lindermann, S., (1993). "Expected Achievement in Speaking Proficiency, 1993” School of Language Studies, Foreign Service Institute, U.S. Department of State, Mimeographed.

Kalmijn, M.: Intermarriage and Homogamy: Causes, Patterns, Trends. $\underline{\text { Annual Review }}$ of Sociology 24:395-421, 1998.

Kantarevic, J.: Interethnic Marriages and Economic Assimilation of Immigrants. IZA Institute for the Study of Labor, Discussion Paper Series No. 1142, Bonn, May 2004.

Lehrer, E. L.: Religious Intermarriage in the United States: Determinants and Trends. Social Science Research 27:245-263, 1998.

Lehrer, E. L.: Age at Marriage and Marital Instability: Revisiting the Becker-LandesMichael Hypothesis. Journal of Population Economics 21(2): 463-484, 2008.

Lichter, D. T., LeClere, F. B., McLaughlin, D. K.: Local Marriage Markets and the Marital Behavior of Black and White Women. The American Journal of Sociology 96:843-867, 1991.

Lichter, D. T., Mclaughlin, D. K., Kephart, G., Landry, D. J.: Race and the Retreat from Marriage: A Shortage of Marriageable Men? American Sociological Review 57:781-799, 1992.

Lichter, D. T., Qian, Z.: Measuring Marital Assimilation: Intermarriage Among Natives and Immigrants. Social Science Research 30:289-312, 2001.

Lieberson, S., Waters, M. C.: From Many Strands: Ethnic and Racial Groups in Contemporary America. New York: Russell Sage Foundation, 1988.

Meng, X., Gregory, R. R.: Intermarriage and the Economic Assimilation of Immigrants. Journal of Labor Economics 23: 135-175, 2005. 
Meng, X., Meurs, D.: Intermarriage, Language, and Economic Assimilation Process: A Case Study of France. IZA - Institute for the Study of Labor, Discussion Paper Series No. 2461, Bonn, November 2006.

Sandefur, G. D. and McKinnell, T.: American Indian Intermarriage. Social Science Research 347: 347-48, 1986.

Schoen, R.: Measuring the Tightness of a Marriage Squeeze. Demography 20:61-78, 1983.

*Schoen, R., Thomas, B.: Intergroup Marriage in Hawaii, 1969-1971 and 1979-1981. Sociological Perspectives 32:365-382, 1989.

Schoen, R., Wooldredge, J.: Marriage Choices in North Carolina and Virginia, 19691971 and 1979-1981. Journal of Marriage and the Family 51:465-481, 1989.

South, S. J., Lloyd, K. M.: Marriage Markets and Nonmarital Fertility in the United States. Demography 29:247-64, 1992a.

Statistical Abstract: 2007 Edition, U.S. Census Bureau, http://www.census.gov/compendia/statab/2007edition.html.

Wilson, W. J.: The Truly Disadvantaged. Chicago: University of Chicago Press, 1987.

Wood, R. G.: Marriage Rates and Marriageable Men: A Test of the Wilson Hypothesis. Journal of Human Resources 30:163-193, 1995. 
Statistical Appendicies for

“Ethnic Intermarriage Among Immigrants:

Human Capital and Assortative Mating

Barry R. Chiswick

and

Christina A. Houseworth 


\section{Appendix A}

Table A-1

Definition of Ancestry 1980 Census Data

\begin{tabular}{|l|l|}
\hline Group & Including: \\
\hline Austrian & \\
\hline Belgian & \\
\hline Icelander & Danish, Faeroe Islander, Greenlander \\
\hline Danish & $\begin{array}{l}\text { Dutch, Dutch-French-Irish, Dutch-German-Irish, } \\
\text { Dutch-Irish-Scotch, Dutch and English Speaking } \\
\text { Belgian }\end{array}$ \\
\hline Dutch & $\begin{array}{l}\text { English, English-French-German, English-French- } \\
\text { Irish, English-German-Irish, English-German-Swedish, } \\
\text { English-Irish-Scotch, English-Scotch-Welsh, Manx }\end{array}$ \\
\hline English & \\
\hline Welsh & \\
\hline Scottish & \\
\hline Finnish & French, French-German-Irish, Alsatian \\
\hline French & $\begin{array}{l}\text { German, German-Irish-Italian, German-Irish-Scotch, } \\
\text { German-Irish-Swedish }\end{array}$ \\
\hline German & \\
\hline Greek & \\
\hline Irish & \\
\hline Italian & \\
\hline Luxemburger & \\
\hline Norwegian & \\
\hline Portuguese & \\
\hline Swedish & \\
\hline Swiss & \\
\hline Scandinavian & \\
\hline & $\begin{array}{l}\text { European, Northern European, Slovak, Andorran, } \\
\text { Armenian, Central European, Croatian, Eastern } \\
\text { European, Georgian, Gibraltan, Lapp, Liechtensteiner, } \\
\text { Maltese, Monegasque, Ruthenian, Serbian, Slav, } \\
\text { Slovene, Southern European, Western European }\end{array}$ \\
\hline European & \\
\hline Albanian & \\
\hline Bulgarian & \\
\hline Czechoslovakian & \\
\hline Estonian & \\
\hline Hungarian & \\
\hline Latvian & \\
\hline Lithuanian & \\
\hline Polish & \\
\hline Rumanian & \\
\hline
\end{tabular}




\begin{tabular}{|l|l|} 
Yugoslavian & \\
\hline Russian & \\
\hline Ukrainian & \\
\hline Byelorussian & Spanish, Spaniard, Basque \\
\hline Spanish & \\
\hline Mexican & \\
\hline Puerto Rican & \\
\hline Cuban & \\
\hline Dominican & \\
\hline Argentinean & \\
\hline Bolivian & Columbian, Providencia, San Andres \\
\hline Chilean & \\
\hline Colombian & \\
\hline Costa Rican & \\
\hline Guatemalan & \\
\hline Honduran & \\
\hline Paraguayan & \\
\hline Peruvian & \\
\hline Uruguayan & \\
\hline Ecuadorian & \\
\hline Venezuelan & $\begin{array}{l}\text { Central and South American, Nicaraguan, Panamanian, } \\
\text { Salvadoran, Surinam }\end{array}$ \\
\hline $\begin{array}{l}\text { South and Central } \\
\text { American }\end{array}$ & Haitian, French West Indies \\
\hline Haitian & \\
\hline Jamaican & \\
\hline Trinidadian/Tobagonian & \\
\hline U.S. Virgin Islander & $\begin{array}{l}\text { British West Indian, Anguilla Islander, British Virgin } \\
\text { Islander, Cayman Islander, Turks and Caicos Islander } \\
\text { Caribbean, Bahamian, Barbadian, Dominica Islander, } \\
\text { Dutch West Indies, St. Christopher Islander, St. Lucia } \\
\text { Islander, Bermudan, Guyanese }\end{array}$ \\
\hline English Speaking West \\
Indies & \\
\hline Belizean & \\
\hline Brazilian & \\
\hline Iranian & \\
\hline Israeli & \\
\hline Jordanian & \\
\hline Lebanese & \\
\hline Syrian & \\
\hline Turkish & \\
\hline Muscat & \\
\hline
\end{tabular}




\begin{tabular}{|c|c|}
\hline $\begin{array}{l}\text { North African, Arabian } \\
\text { Middle Eastern }\end{array}$ & $\begin{array}{l}\text { Middle Eastern, Gazan, Afghan, Arabian, Bahraini, } \\
\text { Bedouin, Iraqi, Kurd, Kuria Muria Islander, Kuwaiti, } \\
\text { Muscat, Omani, Palestinian, People’s Democratic } \\
\text { Republic of Yemen, Qatar, Saudi Arabian, Trucial } \\
\text { Oman, West Bank, Assyrian, Egyptian, Berber, } \\
\text { Tunisian, Algerian, Moroccan, Alhucemas, Libyan, } \\
\text { Yemeni, Aden, Comoros Islander, Rio de Oro, Moor }\end{array}$ \\
\hline South African-White & $\begin{array}{l}\text { Race White: South African, Lesotho, Rhodesian, } \\
\text { Swaziland, Botswana }\end{array}$ \\
\hline South African-Black & $\begin{array}{l}\text { Race Black: South African, Lesotho, Rhodesian, } \\
\text { Swaziland, Botswana }\end{array}$ \\
\hline Sub-Saharan African & $\begin{array}{l}\text { Angolan, Congolese, Djibouti, Ethiopian, Madagascan, } \\
\text {, Mozambican, Namibian, Rio de Oro, Somalian, } \\
\text { Sudanese, Zairian, Zambian, Burundian, } \\
\text { Cameroonian, Central African Republic, Equatorial } \\
\text { Guinea, Gabonese, Kenyan, Rwandan, Tanzanian, } \\
\text { Ugandan, Benin, Cape Verdean, Chadian, Gambian, } \\
\text { Ghanaian, Guinea-Bissau, Guinean, Ivory Coast, } \\
\text { Liberian, Malian, Mauritanian, Niger, Nigerian, } \\
\text { Senegalese, Sierra Leonean, Togo, Kenyan, Upper } \\
\text { Voltan, Afro-American, Eastern Africa, Western } \\
\text { Africa, Central African and Other African }\end{array}$ \\
\hline \multicolumn{2}{|l|}{ Asian Indian } \\
\hline \multicolumn{2}{|l|}{ Pakistani } \\
\hline Chinese & Taiwanese, Singaporean \\
\hline \multicolumn{2}{|l|}{ Filipino } \\
\hline Japanese & Japanese, Okinawan \\
\hline \multicolumn{2}{|l|}{ Korean } \\
\hline $\begin{array}{l}\text { Other Asian: Malaysian \& } \\
\text { Indonesian }\end{array}$ & Asia, Malaysian, Indonesian \\
\hline \multicolumn{2}{|l|}{ Vietnamese } \\
\hline South East Asian & Burmese, Cambodian, Indo-Chinese, Laotian \\
\hline \multicolumn{2}{|l|}{ Australian } \\
\hline \multicolumn{2}{|l|}{ New Zealander } \\
\hline \multicolumn{2}{|l|}{ American Samoan } \\
\hline Hawaiian & Hawaiian, Part Hawaiian \\
\hline Alaskan & Aleut, Eskimo \\
\hline \multicolumn{2}{|l|}{ Guamanian } \\
\hline \multicolumn{2}{|l|}{ Thai } \\
\hline Pacific Islander & $\begin{array}{l}\text { Chamorro Islander, Eastern Archipelago, Fijian, } \\
\text { French Polynesia, French Samoa, Marshall Islander, } \\
\text { Melanesia Islander, Micronesia Islander, Palauan, } \\
\text { Polynesia Islander, Ponapean, Samoan, Tokelau } \\
\text { Islander, Tongan, Truk Islander, Yap Islander, New } \\
\text { Guinean }\end{array}$ \\
\hline
\end{tabular}


Table A-2

Definition of Birthplace Immigrants: 1980 Census Data

\begin{tabular}{|l|l|}
\hline Group & Including \\
\hline England & England, Channel Islands \\
\hline Scotland & \\
\hline Wales & Ireland, Northern Ireland \\
\hline Ireland & \\
\hline Norway & \\
\hline Sweden & Denmark, Faeroe Islands, Greenland \\
\hline Denmark & \\
\hline Netherlands (Dutch) & \\
\hline Belgium & \\
\hline Switzerland & \\
\hline France & East and West Germany \\
\hline Germany & \\
\hline Poland & \\
\hline Czechoslovakia & \\
\hline Austria & \\
\hline Hungary & \\
\hline Yugoslavia & \\
\hline Latvia & \\
\hline Estonia & \\
\hline Lithuania & \\
\hline Finland & \\
\hline Romania & \\
\hline Bulgaria & \\
\hline Greece & \\
\hline Italy & \\
\hline Spain & \\
\hline Portugal & \\
\hline Iceland & \\
\hline Luxembourg & \\
\hline Albania & \\
\hline Turkey & \\
\hline Syria & \\
\hline Lebanon & \\
\hline Israel & \\
\hline Pakistan & \\
\hline India & \\
\hline China & \\
\hline Japan & \\
\hline Korea (n.e.c.) & \\
\hline Philippines & \\
\hline Byelorussia & \\
\hline Ukrainia & \\
\hline
\end{tabular}




\begin{tabular}{|c|c|}
\hline Jordan & \\
\hline Iran & \\
\hline Canada & \\
\hline Mexico & \\
\hline Guatemala & \\
\hline Belize & \\
\hline Honduras & \\
\hline El Salvador & \\
\hline Costa Rica & \\
\hline Cuba & \\
\hline Jamaica & \\
\hline Dominican Republic & \\
\hline Haiti & \\
\hline Trinidad \& Tobago & \\
\hline Venezuela & \\
\hline Ecuador & \\
\hline Peru & \\
\hline Bolivia & \\
\hline Brazil & \\
\hline Paraguay & \\
\hline Uruguay & \\
\hline Chile & \\
\hline Argentina & \\
\hline $\begin{array}{l}\text { Other Central and South } \\
\text { America }\end{array}$ & $\begin{array}{l}\text { Central and South America, Nicaragua, } \\
\text { Panama, Surinam }\end{array}$ \\
\hline Colombia & \\
\hline Vietnam & \\
\hline New Zealand & \\
\hline $\begin{array}{l}\text { North African/Arabian/Middle } \\
\text { Eastern }\end{array}$ & $\begin{array}{l}\text { North Africa, Cyprus, Afganistan, Algeria, } \\
\text { Egypt, Iraq, Kuwait, Libya, Morocco, Qatar, } \\
\text { Saudi Arabia, Tadzhik, Tunisia, Yemen }\end{array}$ \\
\hline Korea & South and North Korea \\
\hline English Speaking West Indies & $\begin{array}{l}\text { Antigua- Barbuda, Bermuda, British Virgin } \\
\text { Islands, British West Indies, Caribbean, } \\
\text { Cayman Islands, Dominica, Guyana, Aruba, } \\
\text { Curacao, Bahamas, Barbados, Grenada, St. } \\
\text { Lucia }\end{array}$ \\
\hline Sub-Saharan Africa & $\begin{array}{l}\text { Angola, Africa, Benin, Burundi, Cameroon, } \\
\text { Cape Verde, Chad, Eastern Africa, Ethiopia, } \\
\text { Gambia, Ghana, Guinea, Guinea-Bissau, Ivory } \\
\text { Coast, Kenya, Liberia, Madagascar, Mauritlus, } \\
\text { Mozambique, Nambia, Niger, Nigeria, } \\
\text { Senegal, Sierra Leone, Somalia, Sudan, } \\
\text { Tanzania, Togo, Uganda, Western Africa, } \\
\text { Zaire, Botswana }\end{array}$ \\
\hline
\end{tabular}




\begin{tabular}{|l|l|} 
South African Black & South Africa, Zimbabwe \\
\hline South African White & South Africa, Zimbabwe \\
\hline Pacific Islander & $\begin{array}{l}\text { Fiji, Micronesia, Papua New Guinea, Tonga, } \\
\text { Western Samoa }\end{array}$ \\
\hline Other Asian & $\begin{array}{l}\text { Burma, Indonesia, Cambodia, Laos, Malaysia, } \\
\text { SE Asia }\end{array}$ \\
\hline Thailand & \\
\hline
\end{tabular}


Table A-3

Intermarriage Rates by Ancestry Group, Married Immigrants Age 18-64 1980 Census Data

\begin{tabular}{|c|c|c|c|}
\hline Ethnicity & $\begin{array}{l}\text { rmarriage } \\
\text { Rate }\end{array}$ & Ethnicity & $\begin{array}{c}\text { Intermarriage } \\
\text { Rate }\end{array}$ \\
\hline Austrian & 79.8 & Costa Rican & 51.5 \\
\hline Belgian & 74.2 & Guatemaian & 38.8 \\
\hline Cypriot & 42.9 & Honduran & 50.3 \\
\hline Icelander & 88.9 & Paraguayan & 66.7 \\
\hline Danish & 67.8 & Peruvian & 53.5 \\
\hline Dutch & 52.1 & Uruguayan & 33.3 \\
\hline English & 52.9 & Venezuelan & 48.8 \\
\hline Welsh & 87.7 & South and Central American & 40.0 \\
\hline Scottish & 70.5 & Haitian & 14.8 \\
\hline Finnish & 53.1 & Jamaican & 30.5 \\
\hline French & 62.0 & Trinidadian/Tobagonian & 30.1 \\
\hline German & 56.0 & U.S. Virgin Islander & 22.2 \\
\hline Greek & 21.6 & English Speaking West Indies & 31.3 \\
\hline Irish & 48.2 & Belizean & 29.6 \\
\hline Italian & 24.4 & Brazilian & 55.6 \\
\hline Luxemburger & 66.7 & Iranian & 42.2 \\
\hline Norwegian & 60.5 & Israeli & 48.4 \\
\hline Portuguese & 14.1 & Jordanian & 36.0 \\
\hline Swedish & 78.0 & Lebanese & 44.0 \\
\hline Swiss & 68.0 & Syrian & 40.8 \\
\hline Albanian & 32.1 & Turkish & 44.0 \\
\hline Bulgarian & 52.3 & Middle Eastern & 29.2 \\
\hline Czechoslovakian & 53.8 & South African- non white & 20.0 \\
\hline Estonian & 50.0 & South African- White & 41.2 \\
\hline Hungarian & 49.7 & Sub Saharan African & 16.0 \\
\hline Latvian & 58.8 & Asian Indian & 10.7 \\
\hline Lithuanian & 44.4 & Pakistani & 17.7 \\
\hline Polish & 39.4 & South East Asian & 14.1 \\
\hline Rumanian & 41.0 & Chinese & 14.9 \\
\hline Yugoslavian & 27.9 & Filipino & 25.8 \\
\hline Russian & 62.0 & Japanese & 50.5 \\
\hline Armenian & 23.3 & Korean & 30.1 \\
\hline Ukrainian & 50.5 & Thai & 57.4 \\
\hline Belorussian & 55.6 & Vietnamese & 21.5 \\
\hline Spanish & 39.1 & Asian & 24.6 \\
\hline Mexican & 12.2 & Australian & 61.4 \\
\hline Puerto Rican & 29.8 & New Zealander & 57.1 \\
\hline Cuban & 23.8 & Guamanian & 16.7 \\
\hline Dominican & 27.8 & Pacific Islander & 29.9 \\
\hline Argentinean & 38.8 & American & 45.2 \\
\hline Bolivian & 50.0 & Canadian & 65.6 \\
\hline
\end{tabular}


Chilean

Colombian

38.7 American Indian

32.9

Source: 1980 Cenusus of Population, Public Use Microdata Sample 
Table A-4

Intermarriage Rates by Country of Birth, Married Immigrants Age 18-64 1980 Census Data

\begin{tabular}{|c|c|c|c|}
\hline Country of Birth & Rate & Country of Birth & Rate \\
\hline Sub- Saharan Africa & 49.9 & Lebanon & 54.5 \\
\hline N. Africa/Mid East & 41.1 & Syria & 59.2 \\
\hline South African (Black) & 60.0 & Turkey & 53.9 \\
\hline South African (White) & 57.7 & Austria & 84.8 \\
\hline Canada & 72.1 & Belgium & 76.0 \\
\hline Argentina & 44.9 & France & 84.2 \\
\hline Bolivia & 57.4 & Luxembourg & 89.5 \\
\hline Brazil & 53.2 & Netherlands & 65.4 \\
\hline Chile & 44.6 & Switzerland & 69.7 \\
\hline Columbia & 35.3 & Albania & 75.0 \\
\hline Ecuador & 41.6 & Andorra & 58.5 \\
\hline Paraguay & 75.0 & Greece & 34.6 \\
\hline Peru & 57.0 & Italy & 43.1 \\
\hline Uruguay & 40.0 & Portugal & 19.3 \\
\hline Venezuela & 53.5 & Spain & 68.1 \\
\hline Other C. and S. Amer. & 56.0 & Yugoslavia & 36.9 \\
\hline Belize & 41.7 & Estonia & 56.5 \\
\hline Costa Rica & 54.2 & Latvia & 64.7 \\
\hline El Salvador & 43.1 & Lithuania & 57.4 \\
\hline Guatemala & 36.7 & Bulgaria & 56.8 \\
\hline Honduras & 51.1 & Czechoslovakia & 62.8 \\
\hline Mexico & 32.4 & Germany & 76.1 \\
\hline Eng. Speak West Indies & 43.2 & Hungary & 57.1 \\
\hline Jamaica & 32.4 & Poland & 46.6 \\
\hline Trinidad and Tobago & 31.3 & Romania & 50.2 \\
\hline Haiti & 14.8 & Denmark & 73.0 \\
\hline Cuba & 21.6 & Finland & 64.9 \\
\hline Dominican Rep. & 28.0 & Iceland & 88.2 \\
\hline China & 21.3 & Ireland & 56.3 \\
\hline Japan & 64.1 & Norway & 65.7 \\
\hline Korea & 33.3 & Sweden & 85.0 \\
\hline India & 17.0 & England & 76.5 \\
\hline Iran & 42.9 & Scotland & 73.1 \\
\hline Pakistan & 37.1 & Wales & 95.6 \\
\hline Burma & 27.3 & Australia & 76.0 \\
\hline Phillippines & 27.5 & New Zealand & 72.0 \\
\hline Thailand & 61.2 & Pacific Islander & 38.3 \\
\hline Vietnam & 24.2 & Byelorussia & 71.4 \\
\hline Israel & 55.2 & Ukrainia & 37.8 \\
\hline Jordan & 40.8 & & \\
\hline
\end{tabular}

Source: 1980 Cenusus of Population, Public Use Microdata Sampl 


\section{Appendix B}

Table B1

Logistic Regression Estimates of Intermarriage for Immigrant Males (Ancestry) 1980 US Census Data

Dependent Variable: Intermarriage

Ethnicity Defined by Ancestry Question

Male $\quad$ Sample Size $=13,820$

\begin{tabular}{|c|c|c|c|c|c|c|}
\hline Variable & Coef & z-score & dy/dx & z-score & $\mathbf{X}$ & Odds Ratio \\
\hline OTHER* & 0.17 & 1.28 & 0.042 & 1.28 & 0.02 & 1.18 \\
\hline BLACK* & -0.40 & -4.46 & -0.096 & -4.62 & 0.05 & 0.67 \\
\hline AMINDIAN* & -0.05 & -0.13 & -0.013 & -0.13 & 0.00 & 0.95 \\
\hline ASIAN* & -0.94 & -14.21 & -0.218 & -16.09 & 0.11 & 0.39 \\
\hline ASINDIAN* & -0.67 & -5.61 & -0.159 & -6.14 & 0.03 & 0.51 \\
\hline HISPANIC* & -0.18 & -2.92 & -0.045 & -2.94 & 0.12 & 0.83 \\
\hline AGMAR31_45* & 0.18 & 3.13 & 0.046 & 3.13 & .167 & 1.2 \\
\hline AGMAR64_* & 0.27 & 1.44 & 0.067 & 1.44 & 0.011 & 1.31 \\
\hline TIMESMAR* & 0.73 & 11.34 & 0.179 & 11.85 & 0.10 & 2.07 \\
\hline HIGHL & 0.00 & 0.41 & 0.001 & 0.41 & 4.12 & 1.00 \\
\hline LOWHI & 0.05 & 4.12 & 0.013 & 4.12 & 1.59 & 1.05 \\
\hline GRADE & 0.11 & 6.05 & 0.028 & 6.05 & 11.96 & 1.12 \\
\hline GRADE2 & 0.00 & -1.3 & 0.000 & -1.3 & 168.58 & 1.00 \\
\hline GRPSIZE & -0.14 & -11.81 & -0.034 & -11.82 & 0.89 & 0.87 \\
\hline AR4 & -0.39 & -6.03 & -0.097 & -6.03 & 0.82 & 0.68 \\
\hline POP & 0.002 & 5.64 & 0.001 & 5.64 & 51.82 & 1.00 \\
\hline AM14_17* & -0.25 & -3.51 & -0.062 & -3.56 & 0.11 & 0.78 \\
\hline AM18_23* & -0.28 & -4.57 & -0.070 & -4.61 & 0.28 & 0.75 \\
\hline AM24_28* & -0.49 & -7.31 & -0.120 & -7.5 & 0.24 & 0.61 \\
\hline AM29_35* & -0.38 & -4.85 & -0.093 & -4.97 & 0.16 & 0.68 \\
\hline AM36_* & -0.33 & -2.58 & -0.080 & -2.65 & 0.04 & 0.72 \\
\hline YSM & 0.01 & 3.7 & 0.002 & 3.7 & 17.22 & 1.01 \\
\hline MULTANC* & 0.35 & 4.62 & 0.087 & 4.65 & 0.07 & 1.42 \\
\hline VET75* & 0.75 & 5.22 & 0.184 & 5.57 & 0.02 & 2.12 \\
\hline VETVIET* & 0.24 & 3.26 & 0.059 & 3.26 & 0.08 & 1.27 \\
\hline VET55_64* & 0.09 & 0.99 & 0.024 & 0.98 & 0.04 & 1.10 \\
\hline VETKOR* & 0.29 & 2.57 & 0.072 & 2.57 & 0.03 & 1.34 \\
\hline VETWWII* & 0.53 & 5.8 & 0.131 & 5.94 & 0.05 & 1.70 \\
\hline _cons & -1.07 & -5.92 & & & & \\
\hline
\end{tabular}

Source: 1960 to 1980 Censuses of Population, Public Use Microdata Sample. 
Table B2

Logistic Regression Estimates of Intermarriage for Immigrant Females

1980 US Census Data

Dependent Variable: Intermarriage

Ethnicity Defined by Ancestry Question

\begin{tabular}{lrrrrrr} 
Female & Sample Size $=15,317$ & \multicolumn{3}{c}{ Pseudo R2 $=.1279$} \\
\hline & \multicolumn{1}{c}{ Coef } & z-score & dy/dx & z-score & \multicolumn{1}{c}{ X } & Odds Ratio \\
\hline LINGDIS & -0.0035 & -2.49 & -0.001 & -2.49 & 2.69 & 1.00 \\
OTHER* & -0.17 & -1.16 & -0.043 & -1.16 & 0.01 & 0.84 \\
BLACK* & -0.53 & -5.57 & -0.130 & -5.72 & 0.04 & 0.59 \\
AMINDIAN* & 0.07 & 0.18 & 0.018 & 0.18 & 0.00 & 1.08 \\
ASIAN* & -0.18 & -3.31 & -0.045 & -3.31 & 0.16 & 0.83 \\
ASINDIAN* & -1.58 & -9.61 & -0.344 & -13.29 & 0.02 & 0.21 \\
HISPANIC* & -0.16 & -2.31 & -0.039 & -2.31 & 0.09 & 0.86 \\
AGMAR31_45* & 0.31 & 4.28 & 0.075 & 4.28 & 3.16 & 1.56 \\
AGMAR64_* & 0.53 & 2.05 & 0.126 & 2.05 & 0.28 & 2.78 \\
TIMESMAR* & 0.88 & 13.48 & 0.206 & 15.1 & 0.10 & 2.42 \\
HIGHL & 0.01 & 1.07 & 0.001 & 1.07 & 3.61 & 1.01 \\
LOWHI & 0.03 & 3.64 & 0.009 & 3.64 & 1.73 & 1.04 \\
GRADE & 0.15 & 8.63 & 0.037 & 8.63 & 11.52 & 1.16 \\
GRADE2 & 0.004 & -4.99 & -0.001 & -4.99 & 149.24 & 1.00 \\
GRPSIZE4 & -0.14 & -12.28 & -0.035 & -12.27 & 0.82 & 0.87 \\
AR4 & -0.55 & -7.13 & -0.137 & -7.13 & 0.68 & 0.58 \\
POP & 0.002 & 5.61 & 0.001 & 5.61 & 46.95 & 1.00 \\
AM14_17* & -0.42 & -6.29 & -0.105 & -6.36 & 0.12 & 0.66 \\
AM18_23* & -0.34 & -6.14 & -0.086 & -6.16 & 0.32 & 0.71 \\
AM24_28* & -0.21 & -3.32 & -0.051 & -3.31 & 0.22 & 0.81 \\
AM29_35* & -0.22 & -2.78 & -0.054 & -2.78 & 0.11 & 0.81 \\
AM36_* & -0.22 & -1.7 & -0.055 & -1.7 & 0.03 & 0.80 \\
YSM & -0.01 & -2.24 & -0.001 & -2.24 & 16.58 & 0.99 \\
MULTANC* & 0.40 & 5.87 & 0.099 & 6.06 & 0.08 & 2.98 \\
SPSVET* & 1.09 & 27.49 & 0.263 & 29.26 & 0.40 & \\
_ons & -0.980 & -6.45 & & & & \\
\hline
\end{tabular}

Source: 1960 to 1980 Censuses of Population, Public Use Microdata Sample. 
Table B3

Logistic Regression Estimates of Intermarriage for Immigrant Males (Country of Birth)

1980 US Census Data

\section{Dependent Variable: Intermarriage}

Ethnicity Defined by Country of birth

\begin{tabular}{|c|c|c|c|c|c|c|}
\hline \multirow[t]{2}{*}{ Male } & \multicolumn{4}{|c|}{$\begin{array}{l}\text { Sample Size } \\
=13,820\end{array}$} & \multicolumn{2}{|c|}{ Pseudo R2 =.1260 } \\
\hline & Coefficien & & & & & \\
\hline Variable & $\mathbf{t}$ & z-score & $\mathrm{dy} / \mathrm{dx}$ & z-score & $\mathbf{X}$ & Odds Ratio \\
\hline OTHER* & 0.26 & 1.87 & 0.053 & 1.97 & 0.02 & 1.29 \\
\hline BLACK* & -0.59 & -6.14 & -0.137 & -5.84 & 0.05 & 0.56 \\
\hline AMINDIAN* & 0.18 & 0.39 & 0.038 & 0.41 & 0.00 & 1.20 \\
\hline ASIAN* & -1.15 & -17.42 & -0.274 & -17.19 & 0.11 & 0.32 \\
\hline ASINDIAN* & -0.69 & -5.84 & -0.164 & -5.55 & 0.03 & 0.50 \\
\hline HISPANIC* & 0.00 & -0.05 & -0.001 & -0.05 & 0.12 & 1.00 \\
\hline AGMAR31_45* & -0.33 & -5.59 & -0.073 & -6.05 & 0.168 & 0.81 \\
\hline AGMAR64_* & -0.48 & -2.5 & -0.111 & -2.72 & 0.012 & 0.90 \\
\hline TIMESMAR* & 1.00 & 11.86 & 0.180 & 15.2 & 0.10 & 2.72 \\
\hline HIGHL & 0.01 & 1.59 & 0.002 & 1.59 & 3.85 & 1.01 \\
\hline LOWHI & 0.02 & 1.51 & 0.004 & 1.51 & 1.44 & 1.02 \\
\hline GRADE & 0.03 & 1.99 & 0.007 & 1.99 & 11.96 & 1.03 \\
\hline & & & & & 168.5 & \\
\hline GRADE2 & 0.00 & 1.21 & 0.000 & 1.21 & 8 & 1.00 \\
\hline GRPSIZE & -0.04 & -3.79 & -0.009 & -3.79 & 0.89 & 0.96 \\
\hline AR & -0.25 & -3.53 & -0.054 & -3.53 & 0.86 & 0.78 \\
\hline POP & 0.00 & 1.02 & 0.000 & 1.02 & 51.82 & 1.00 \\
\hline AM14_17* & -0.61 & -7.71 & -0.140 & -7.38 & 0.11 & 0.55 \\
\hline AM18_23* & -0.60 & -8.61 & -0.134 & -8.39 & 0.28 & 0.55 \\
\hline AM24_28* & -0.59 & -8 & -0.134 & -7.75 & 0.24 & 0.55 \\
\hline AM29_35* & -0.20 & -2.25 & -0.044 & -2.2 & 0.16 & 0.82 \\
\hline AM36_* & 0.36 & 2.56 & 0.073 & 2.76 & 0.04 & 1.43 \\
\hline YSM & 0.04 & 12.86 & 0.008 & 12.86 & 17.22 & 1.04 \\
\hline MULTANC* & 0.65 & 6.7 & 0.125 & 7.81 & 0.07 & 1.92 \\
\hline VET75* & 0.74 & 4.52 & 0.137 & 5.53 & 0.02 & 2.10 \\
\hline VETVIET* & 0.24 & 2.89 & 0.050 & 3.02 & 0.08 & 1.27 \\
\hline VET55_64* & 0.17 & 1.54 & 0.036 & 1.59 & 0.04 & 1.19 \\
\hline VETKÖR* & 0.24 & 1.82 & 0.050 & 1.91 & 0.03 & 1.27 \\
\hline VETWWII* & 1.77 & 10.5 & 0.257 & 19.48 & 0.05 & 5.86 \\
\hline _cons & 0.08 & 0.51 & 0.054 & 2.11 & 0.40 & \\
\hline
\end{tabular}

Source: 1960 to 1980 Censuses of Population, Public Use Microdata Sample. 


\section{Table B4}

\section{Logistic Regression Estimates of Intermarriage for Immigrant Females (Country of Birth)}

1980 US Census Data

Dependent Variable: Intermarriage

Ethnicity Defined by Country of Birth

\begin{tabular}{lrrrrrr} 
Female & \multicolumn{3}{c}{ Sample Size $=15,317$} & \multicolumn{2}{c}{ Pseudo R2 $=.2377$} \\
\hline & Coefficient & z-score & dy/dx & z-score & \multicolumn{1}{c}{ X } & \multicolumn{1}{c}{ Rdds } \\
\hline OTHER* & 0.01 & 0.07 & 0.002 & 0.07 & 0.01 & 1.01 \\
BLACK* & -0.97 & -9.18 & -0.211 & -8.21 & 0.04 & 0.38 \\
AMINDIAN* & 0.20 & 0.41 & 0.034 & 0.44 & 0.00 & 1.22 \\
ASIAN* & -0.55 & -8.78 & -0.108 & -8.16 & 0.16 & 0.58 \\
ASINDIAN* & -1.31 & -8.15 & -0.297 & -7.43 & 0.02 & 0.27 \\
HISPANIC* & -0.10 & -1.49 & -0.019 & -1.46 & 0.09 & 0.90 \\
AGMAR31_45* & -0.22 & -2.75 & -0.042 & -3.27 & 0.09 & 0.80 \\
AGMAR64_* & -0.39 & -1.37 & -0.077 & -1.71 & 0.006 & 0.68 \\
TIMESMAR* & 1.38 & 13.44 & 0.180 & 20.54 & 0.10 & 3.97 \\
HIGHL & 0.01 & 1.36 & 0.002 & 1.36 & 3.41 & 1.01 \\
LOWHI & 0.004 & -0.35 & -0.001 & -0.35 & 1.56 & 1.00 \\
GRADE & 0.03 & 1.95 & 0.006 & 1.95 & 11.52 & 1.03 \\
GRADE2 & 0.00 & -0.3 & 0.000 & -0.3 & 149.24 & 1.00 \\
GRPSIZE & -0.08 & -6.6 & -0.014 & -6.59 & 0.73 & 0.93 \\
AR & -0.49 & -5.31 & -0.088 & -5.31 & 0.72 & 0.61 \\
POP & 0.0002 & 1.73 & 0.000 & 1.73 & 46.95 & 1.00 \\
AM14_17* & -0.58 & -7.85 & -0.115 & -7.2 & 0.12 & 0.56 \\
AM18_23* & -0.40 & -6.36 & -0.074 & -6.15 & 0.32 & 0.67 \\
AM24_28* & -0.05 & -0.75 & -0.010 & -0.74 & 0.22 & 0.95 \\
AM29_35* & 0.48 & 4.91 & 0.078 & 5.52 & 0.11 & 1.61 \\
AM36_* & 0.96 & 5.97 & 0.133 & 8.29 & 0.03 & 2.62 \\
YSM & 0.03 & 11.82 & 0.006 & 11.8 & 16.58 & 1.03 \\
MULTANC* & 0.89 & 8.97 & 0.130 & 11.7 & 0.08 & 2.45 \\
SPSVET* & 1.93 & 35.98 & 0.311 & 43.73 & 0.40 & 6.88 \\
Cons & -0.19 & -1.27 & & & & \\
\hline & & & & & &
\end{tabular}

Source: 1960 to 1980 Censuses of Population, Public Use Microdata Sample. 